\title{
COLLECTIVE MEMORY "JUM'AT KELABU" DI BANJARMASIN (PERSPEKTIF RESOLUSI KONFLIK ATAS PERISTIWA 23 MAY 1997)
}

\author{
Husnul Khotimah \\ Prodi Agama dan Filsafat, Konsentrasi Studi Agama dan Resolusi Konflik \\ Pascasarjana UIN Sunan Kalijaga, Yogyakarta \\ husnulkhotimah240@gmail.com
}

\begin{abstract}
:
This study intends to explore the events of the conflict on 23 May 1997 from the aspect of the peaceful resolution. Where a peacebuilding effort is needed to maintain a peaceful situation. With the collective memory being represented in the present mass, it is part of the form of efforts in fostering post-conflict sustainable peace. Through the elements of society (Non-Governmental Actor) the memory of conflict is represented in the public sphere as a form of warning against forgetting over history.The role of a nongovernmental actor in peacebuilding has a strategic role in resolving conflicts and building peace post-conflict. This research is a qualitative research, using a sociology-historical approach. The conflict that occurred in Banjarmasin city has a long chronology, the cause of this conflict is an unclear campaign route, the party base that controls Banjarmasin, because the mass of one the OPP that interfere with the Friday prayer, and aggressiveness of campaign participants. The form of peacebuilding efforts of the elements of society is to take peaceful action down the street, discussion/dialogue, and watching a documentary film. Elements of society argue that bringing back the memory of the conflict has two impacts: negative and positive impacts on people's lives thereafter. These efforts need to be built to create an awareness that the conflict is painful, unpleasant and disturbing so hopefully it will never happen again.

Keywords: Collective Memory, Jum'at Kelabu, Peace Building, Non Governmental Actor, and Conflict Resolution.
\end{abstract}




\section{Pendahuluan}

Keberadaan negara bangsa (nation state) merupakan kesepakatan final dari para founding fathers sebagai bentuk pengakuan terhadap pluralitas yang menjadi pilar tegaknya negara Indonesia. Dengan tegas kemajemukan ini tertuang dalam lambang negara Bhineka Tunggal Ika. Dalam sejarah bangsa Indonesia, kemajemukan telah melahirkan perpaduan yang sangat indah dalam berbagai bentuk mozaik budaya. Berbagai suku, agama, adat istiadat dan budaya dapat hidup berdampingan dan memiliki ruang negosiasi yang sangat tinggi dalam kehidupan bermasyarakat. Namun, keragaman yang harmoni tersebut kemudian ternodai oleh sikap ekslusif yang tumbuh dari akar primordialisme sempit kesukuan, agama dan golongan. ${ }^{1}$

Konflik dan kerusuhan sosial yang meledak diberbagai kota di Indonesia belakangan ini tidak berlangsung dalam ruang kosong. Konflik dan kerusuhan itu terjadi dalam realitas sosial dan politik tertentu. Oleh karena itu, analisis terhadap setiap konflik dan kerusuhan sosial yang meledak tidak cukup hanya dengan melihat aktor-aktor yang terlibat di dalamnya, baik dari perspektif entitas maupun agama. Analisis konflik dan kerusuhan tersebut harus juga memperhatikan faktor-faktor seperti sosial, politik dan ekonomi. ${ }^{2}$

Masyarakat Indonesia yang terdiri dari berbagai macam suku, agama, dan kelompok ini memiliki potensi yang besar terjadinya konflik sosial, baik yang dilatarbelakangi agama maupun persoalan politik, budaya dan etnik. Karena Indonesia memiliki masyarakat yang sangat majemuk (beterogen). Berbagai pertikaian etnis, menunjukkan bahwa Indonesia bukan sekedar sedang menghadapi persoalan perbedaan dua etnis, tetapi persoalan struktural yang lebih rumit. Struktur masyarakat Indonesia mencerminkan sistem sosial budaya yang majemuk, baik secara horizontal maupun vertikal. Secara horizontal ditandai dengan kenyataan bahwa adanya kesatuan-kesatuan entitas yang didasari perbedaan suku bangsa, adat, agama, bahasa, dan ciri-ciri kedaerahan lainnya. Sedangkan secara vertikal ditandai perbedaan-perbedaan sosial yang

${ }^{1}$ Titik Suwariyati, "Konflik-konflik Sosial Bernuansa Agama di Berbagai Komunitas: Kasus Kerusuhan Sosial di Banjarmasin 1997”, Departemen Agama RI, Konflik Sosial Bernuansa Agama di Indonesia (Jakarta: Badan Litbang Agama dan Diklat Keagamaan, Puslitbang Kehidupan Beragama, Bagian Proyek Peningkatan Kerukunan Hidup Umat Beragama, 2003), 1.

${ }^{2}$ Mursyid Ali (ed.), "Pengantar", Pemetaan Kerukunan Kebidupan Beragama di Berbagai Daerah di Indonesia (Jakarta: Puslitbang Kehidupan Keagamaan, 2009), vii. 
cukup tajam. Perbedaan-perbedaan tersebut jika tidak dijembatani oleh pemerintah daerah setempat pada situasi tertentu dapat menimbulkan konflik. ${ }^{3}$

Konflik merupakan suatu peristiwa yang sangat mungkin terjadi dalam hubungan interaksi antar individu atau antar kelompok individu, setiap individu pada dasarnya mempunyai potensi konflik dalam bawah sadarnya. Potensi konflik tersebut akan menjadi tindakan konflik apabila situasi memungkinkan. Konflik biasanya terjadi karena adanya perbedaan kepentingan. Dalam setiap peristiwa konflik selalu terbentuk polarisasi pihak-pihak yang berkonflik. Namun, tidak selamanya konflik itu bernilai negatif. ${ }^{4}$ Karena konflik juga dapat menciptakan tatanan sosial yang lebih baik jika berlangsung secara terkendali. ${ }^{5}$

Jika dilihat, nampaknya kerusuhan atau konflik sosial memang telah menjadi gejala yang umum bagi perjalanan hidup bangsa Indonesia. Dari tahun 1995 tercatat terjadi beberapa peristiwa kerusuhan baik yang bernuansa agama maupun sosial, seperti di Purwakarta (31 Oktober 2 November 1995), Pekalongan (24 November 1995), Jakarta (27 Juli 1996), Situbondo (10 Oktober tahun 1996), Tasikmalaya (26 Desember 1996), Sanggau Ledo (30 Desember 2 Januari 1997), Tanah Abang (28 Januari 1997), dan Rengasdengklok (31 Januari 1997), Karawang tahun 1997 dan Mei 1998 yang terkenal dengan nama 'Tragedi Mei' di Jakarta, Solo, Surabaya, Palembang dan Medan serta kerusuhan-kerusuhan lainnya. ${ }^{6}$

Banjarmasin merupakan salah satu kota di Indonesia yang dikenal dengan masyarakatnya yang hidup rukun, harmoni dan religius ini pun tidak luput dari yang namanya konflik atau kerusuhan. Selain terkenal dengan julukan 'Kota Seribu Sungai', Kota Banjarmasin ini juga terkenal dengan sebutan 'Kota Seribu Langgar' dengan banyaknya bangunan rumah ibadah berupa masjid, langgar (Surau) yang sangat mudah ditemui, Taman Pendidikan Al-Qur'an (TPA), sarana pendidikan yang berbasis pondok pesantren, majelis-majelis

${ }^{3}$ Darman Siregar, "Peta Daerah Konflik di Indonesia: Akar Masalah dan Pola Menaggulangi", Jurnal Harmoni I, No. 3, (Juli-September 2003), 3.

${ }^{4}$ Menurut Pendekatan Fungisonal, konflik tidak selalu bersifat negatif, tetapi juga dapat bersifat positif. Adanya konflik dengan kelompok eksternal dapat berfungsi meredam konflik internal. Konflik dengan pihak luar dapat menggalang rasa persatuan kelompok identitas dan solidaritas kelompok menjadi kuat. Hubungan antar anggota kelompok menjadi semakin erat. Dengan demikian kelestarian kelompok dapat terjaga.

${ }^{5}$ Gunawan Sumodiningrat dan Ari Wulandari, Revolusi Mental: Pembentukan Karakter Bangsa Indonesia (Yogyakarta: Media Pressindo, 2015), 131.

${ }^{6}$ Hairus Salim HS dan Andi Achdian, Amuk Banjarmasin (Jakarta: Yayasan Lembaga Bantuan Hukum Indonesia (YLBHI), 1997), 7. 
ta'lim serta banyaknya "Tuan Guru" yang dihormati turut pula mewarnai kehidupan keagamaan masyarakat Banjarmasin. Salah satu tokoh penyebar agama Islam yang terkenal di Kalimantan Selatan adalah Syeikh Muhammad Arsyad Al-Banjari pengarang Kitab Sabilal Mubtadin dan juga Syeikh Muhammad Nafis Al-Banjari dengan karyanya Kitab Durr Al-Nafis yang masih dibaca hingga sekarang. Selain itu ada pula para habaib dan datu-datu yang terkenal dengan kekeramatannya seperti Datu Abulung, Datu Nuraya, Datu Sanggul dan datu-datu lainnya yang turut mewarnai penyebaran Islam di wilayah tersebut.

Saat itu, menjelang pemilu pada tahun 1997 bermula dari reaksi terhadap "gangguan" shalat Jum'at di Masjid Noor dari para simpatisan Partai Golkar yang sedang berkampanye ketika itu, tampaknya menjadi "pemicu" peristiwa kerusuhan di Banjarmasin. Kemarahan massa dibeberapa tempat yang merasa shalat Juma'atnya terganggu geram dengan tingkah laku beberapa simpatisan Partai Golkar. Kejengkelan merata inilah yang mereka rasakan dan membuat massa kemudian datang secara bergelombang. Jika diamati dari satu sisi kejadian maka, inilah yang menjadi salah satu faktor penyebab pecahnya konflik pada 23 Mei 1997 yang dikenal dengan sebutan "Jum'at Kelabu" atau "Jum'at Membara". 8

Pada hari itu Banjarmasin dilanda kerusuhan massal, menyusul kampanye Partai Golkar pada hari terakhir putaran kampanye menjelang pemilu tahun 1997. Dilihat dari skala kerusuhan dan jumlah korban jiwa serta kerugian fisik, peristiwa "Jumat Kelabu" adalah yang terbesar di Indonesia pada waktu itu dalam sejarah Orde Baru. Namun, akibat ketertutupan pemerintah, tidak ada laporan akurasinya data yang bisa dipercaya penuh, mengenai apa yang sesungguhnya terjadi di lapangan pada waktu itu. Dibandingkan dengan skala tersebut, berita-berita pers sangat terbatas dan tidak sebanding dalam pemberitaan di media. ${ }^{9}$

Sebelumnya, beberapa wilayah telah digoncang oleh kerusuhan yang bernuansa SARA. Namun, peristiwa "Jumat Kelabu" yang sempat menarik perhatian nasional dan internasional ini segera terlupakan dan seperti dianggap tidak ada. Hal ini karena pertama, peristiwa itu dianggap sebagai musibah biasa saja. Masih kuatnya represi membuat sebagian besar saksi mata tidak berani

\footnotetext{
${ }^{7}$ Sebutan orang Banjar untuk orang yang ahli dalam agama Islam. Istilah ini seperti sebutan kyai bagi orang Jawa.

${ }^{8}$ Departemen Agama RI, Konflik. Sosial Bernuansa Agama di Indonesia, 12.

${ }^{9}$ Hairus Salim HS danAndi Achdian, Amuk Banjarmasin, 41 dan 44.
} 
buka mulut, bahkan untuk melaporkan anggota keluarga yang hilang pun mereka takut. Lebih-lebih ketika itu ada stigma yang kuat bahwa mereka yang terlibat dalam peristiwa itu adalah "para perusuh", "para penjarah/pencuri". Demikianlah, peristiwa kerusuhan 23 Mei 1997 itu dibenak masyarakat sehingga ingin segera dilupakan dan menjadi berbahaya untuk diingat.

Kedua, setahun setelah peristiwa itu dan rupanya inilah ujung dari berbagai rentetan kerusuhan di berbagai kota di Indonesia yaitu, terjadinya reformasi yang kemudian memakzulkan rezim Presiden Soeharto. Peristiwa reformasi yang skala dan dampaknya memang lebih besar ini, akhirnya menutup habis ingatan akan peristiwa kerusuhan sosial yang terjadi di berbagai daerah, termasuk peristiwa "Jumat Kelabu", fokus perhatian kemudian beralih ke pentas nasional.

Bagaimanapun juga peristiwa itu pernah terjadi, tidak bisa dilupakan begitu saja dan harus menjadi pelajaran untuk pembangunan daerah yang lebih baik pasca kerusuhan. Meledaknya kerusuhan di Kota Banjarmasin sebagai situs kerusuhan tentu juga didukung oleh keadaan sosial yang tidak kondusif. Bagaimana mungkin dalam waktu yang sedemikian singkat terjadi kerusuhan yang demikian massif, dengan seratus lebih korban jiwa jika akar-akar kerusuhan yang bersifat sosial-politik tidak mendukungnya. Jadi, jika akar-akar kerusuhan sosial ini tidak diperbaiki, bukan tidak mungkin suatu saat kerusuhan yang kurang lebih sama akan terulang kembali. Hal ini terutama di saat-saat transisi dan peralihan kekuasaan politik, ketika keadaan keamanan tidak stabil dan ekonomi demikian sulit. ${ }^{10}$

Cerita tentang kerusuhan "Jum'at Kelabu" di Banjarmasin ini, menggambarkan salah satu dari serentetan konflik diberbagai daerah di Indonesia yang terjadi. Isu yang menonjol dalam cerita ini sebenarnya adalah kerusuhan yang berakar pada kekecewaan masyarakat pada prestasi kerja politik dan ekonomi Orde Baru selama ini. Dengan kata lain, kerusuhan itu merupakan akibat dari reaksi masyarakat terhadap kekerasan yang mereka alami selama ini. ${ }^{11}$ Namun, kerusuhan atau konflik yang terjadi juga mampu menghasilkan dua dampak sekaligus yaitu konstruktif (positif) dan deskruktif

\footnotetext{
${ }^{10}$ Hairus Salim HS, "10 Tahun Amuk "Jum'at Kelabu dan Munir". https://haisa.wordpress.com/2007/05/23/10-tahun-amuk-jumat-kelabu-danmunir/\#comment-345. Diakses tanggal 11 November 2015.

${ }^{11}$ Mohtar Mas'oed, 'Pengantar' Kekerasan? Siapa Melakukan Tindak Kekerasan?, Hairus Salim HS dan Andi Achdian, Amuk Banjarmasin, ix.
} 
(negatif). Sehingga kerusuhan itu tidak selamanya hanya berbuah negatif jika kiranya dilakukan penaganan yang tepat terhadap konflik.

Kerusuhan yang terjadi di Kalimantan Selatan khususnya Kota Banjarmasin ini, boleh dikata mengejutkan karena terjadi di kota yang selama ini digambarkan rukun, harmoni, religius dan kaya akan budaya lokal masyarakatnya (local wisdom) yang masih terjaga hingga sekarang, dimana masyarakat hidup berdampingan secara damai dan aman. Beberapa kecenderungan konflik rasial, sektarian dan lainnya hampir tidak dikenal di kota ini. Adanya peristiwa kerusuhan ini melahirkan ketidakpercayaan dan pertanyaan besar mengapa peristiwa itu bisa terjadi pada masyarakat Banjar yang sangat jauh dari nilai budaya Banjar. Ini mengisyaratkan bahwa situasi yang damai belum tentu tidak mengandung konflik.

Agar potensi konflik tidak menjadi kasus konflik maka dalam hal ini dibutuhkan yang namanya pengendalian. Pengendalian potensi konflik dapat dilakukan baik sebelum terjadi kasus konflik maupun setelah penyelesaian konflik. Ini sejalan dengan pandangan bahwa proses konflik-integrasi dalam masyarakat silih berganti. Selain itu, karena sering terjadi penyelesaian konflik justru menyisakan konflik lanjutan karena prosesnya dianggap kurang memuaskan salah satu atau kedua belah pihak.

Pengendalian sosial adalah proses mengajak atau memaksa anggota masyarakat agar mematuhi kaidah-kaidah dan nilai-nilai sosial yang berlaku dengan tujuan untuk mencapai keserasian antara stabilitas dengan perubahan yang terjadi dalam masyarakat. Menurut Johan Galtung ada tiga tahap dalam penyelesaian konflik salah satunya yaitu dengan Peace Building. Peace Building adalah tindakan untuk mengidentifikasi dan mendukung struktur-struktur guna memperkuat perdamaian untuk mencegah suatu konflik yang telah didamaikan berubah kembali menjadi konflik. ${ }^{12}$ Peace Building menurut Galtung lebih menekankan kepada proses jangka panjang, penelusuran dan penyelesaian akar konflik, mengubah asumsi-asumsi yang kontradiktif, serta memperkuat elemen yang dapat menghubungkan pihak-pihak yang bertikai dalam suatu formasi baru demi mencapai perdamaian positif.

Paparan Galtung ini diperkuat Andi Knight, ilmuwan politik Kanada, dalam bukunya Building Sustainable Peace yang menyatakan bahwa peace building terkait dengan dua hal esensial yaitu dekonstruksi struktur kekerasan dan merekonstruksi struktur perdamaian. Strategi peace building memiliki tahapan-

${ }^{12}$ M. Mukhsin Jamil, Resolusi Konflik: Model dan Strategi; dalam Mengelola Konflik. Membangun Damai (Semarang: Wali Songo Media Center, 2007), 34. 
tahapan waktu yang meliputi short-term ( 2 bulan-2 tahun), mid-term (2-5 tahun), long-term (5-10 tahun) serta mencakup berbagai dimensi seperti politik, ekonomi, sosial dan internasional. Peace Building umumnya dilakukan oleh aktor domestik seperti masyarakat, pemerintah, dan lembaga swadaya masyarakat (LSM), namun tidak dipungkiri aktor eksternal seperti organisasi internasional, negara donor, dan International Non-Governmental Organizations (INGO's) memiliki peranan penting dalam memfasilitasi dan mendukung upaya peace building. ${ }^{13}$ Peace Building lahir setelah berlangsungnya konflik.

Selain itu pentingnya memori (mengingat dan melupakan) menjadi motor dibalik perkembangan sosial baru yang memiliki peran dan pengaruh yang sangat penting dalam perubahan dan pemulihan pasca konflik. Penelitian para psikolog mendemonstrasikan sejauhmana memori tunduk pada perubahan waktu dan manipulasi (diri), isu-isu yang menjadi kontroversial secara politik melalui memori dapat "terpulihkan". Sementara itu, sejarawan dan ilmuwan sosial yang mempelajari praktek-praktek memori abad ke-20 memperhalus pemahaman Maurice Halbwachs bahwa terdapat hubungan antara diskursus, praktek, ekspektasi sosial yang berubah dan cara individu mengingat masa lalu.

Dalam hal ini, memori masa silam mengenai konflik dari berbagai kalangan yang terlibat dibangun kembali dengan berbagai cara sebagai jalan evaluasi agar konflik yang serupa ataupun yang berbeda tidak terjadi lagi. Karena memori kolektif ini akan tetap ada dan dapat diwariskan dari generasi ke generasi berikutnya, meskipun waktu telah berubah dan tradisi telah menghilang. Oleh karenanya, peran para elemen-elemen masyarakat sangat berpengaruh serta masyarakat secara luas juga memiliki kontribusi yang besar dalam menciptakan memori positif dan perdamaian di masa depan. Memori kolektif akan konflik tersebut diharapkan dapat berperan sebagai fasilitator perdamaian dalam menyembuhkan luka konflik yang terlajur tergores di hati dan kehidupan masyarakat Kota Banjarmasin.

\section{Metode Penelitian}

Penelitian ini adalah penelitian lapangan (field research), yaitu jenis penelitian yang menggunakan informasi yang diperoleh dari sasaran penelitian yaitu responden dan informan melalui instrumen pengumpulan data dengan angket, observasi, wawancara dan dokumentasi. ${ }^{14}$ Dimana sejumlah keterangan dan data yang diperlukan diambil langsung dari lokasi penelitian yaitu, lokasi

\footnotetext{
${ }^{13}$ http:/ / kapotha.blogspot.co.id/2010/11/peacebuilding.html. Diakses pada 24 Juli 2016.

${ }^{14}$ Rahmadi, Pengantar Metodologi Penelitian (Banjarmasin: Antasari Press, 2011), 13.
} 
dimana kerusuhan Jum'at Kelabu itu terjadi. Namun, sebelumnya penulis juga mengumpulkan beberapa bahan-bahan kepustakaan (library research), sebagai landasan acuan penggalian data dan melengkapi hasil wawancara yang dilakukan sehingga semua pertanyaan dapat terjawab dengan baik.

Penelitian lapangan ini bersifat deskriptif-kualitatif. Desain penelitian deskriptif-kualitatif ini berusaha menuturkan pemecahan masalah yang ada sekarang berdasarkan data-data, penyajian data, menganalisis dan menginpretasikannya. ${ }^{15}$ Sedangkan pendekatan yang digunakan adalah pendekatan sosiologi-historis. Pendekatan ini berusaha mempelajari hidup bersama dalam masyarakat dan menyelidiki ikatan-ikatan antara manusia yang menguasai hidupnya. Dengan pendekatan ini suatu fenomena sosial dapat dianalisis dengan faktor-faktor yang mendorong terjadinya hubungan, mobilitas sosial serta keyakinan-keyakinan yang mendasari terjadinya proses tersebut. ${ }^{16}$ Dalam hal ini pendekatan sosiologi akan mempermudah mengetahui bagaimana memori mengingat dan melupakan berperan bagi perdamaian di Kota Banjarmsin pasca konflik.

Penelitian ini berlokasi di Kecamatan Banjarmasin Tengah Kota Banjarmasin, Kabupaten Banjar, Provinsi Kalimantan Selatan. Sedangkan yang menjadi subjek dalam penelitian ini adalah informan (sumber informasi) yaitu mereka yang memiliki pengetahuan dan pengalaman mengenai sejumlah aspek yang akan diteliti, yaitu berbagai pihak yang mengetahui bagaimana kerusuhan di Banjarmasin dan terlibat langsung. Serta data-data yang terkait objek yang akan diteliti. Dan subjek penelitian ini adalah tokoh agama-agama, masyarakat umum, aktivis, ormas, LSM, media massa (cetak dan televisi), aparat penegak hukum, pemerintah dan lain-lain. Informan dipilih berdasarkan karakteristik sebagai berikut: 1). Mengetahui peristiwa konflik tahun 1997, 2). Informan berada di Kota Banjarasin, Kabupaten Banjar, 3). Memiliki otoritas kepemimpinan, baik dalam organisasi keagamaan maupun organisasi sosial kemasyarakatan bagi tokoh agama, 4). Oknum-oknum yang terlibat dalam penyelesaian konflik itu sendiri, 5). Kelompok-kelompok masyarakat yang menghadirkan kembali memori kolektif.

Teknik pengumpulan data yang digunakan adalah teknik snow ball, dan untuk mendapatkan data yang relevan maka dilakukanlah observasi, wawancara mendalam terhadap sumber informasi yang dianggap memiliki kompetensi

\footnotetext{
${ }^{15} \mathrm{Abu}$ Achmad dan Cholid Narbuka, Metode Penelitian (Jakarta: Bumi Angkasa, 2002), 44.

${ }^{16}$ Abuddin Nata, Metodologi Studi Islam (Jakarta: Raja Grafindo Persada, 2008), 38-39.
} 
dalam masalah yang akan diteliti, dokumenter/dokumentasi dan bahan-bahan berupa literatur-literatur yang berkaitan dengan permasalahan yang diteliti.

\section{Pembahasan}

\section{Potret Kota Seribu Sungai Menjelang Konflik}

1. Kecamatan Banjarmasin Tengah Sebagai Daerah Pusat Konflik

Kecamatan Banjarmasin Tengah merupakan pusat Kota Banjarmasin, Kalimantan Selatan karena letaknya yang persis berada ditengah-tengah Indonesia. Memiliki luas $11,66 \mathrm{~km}^{2}$, dengan ibukota kecamatan yang terletak di Kelurahan Teluk Dalam. Keadaan geografi kecamatan ini terletak pada ketinggian 0,16 meter. Kecamatan Banjarmasin Tengah juga berbatasan langsung dengan kecamatan-kecamatan lain yang berada Kota Banjarmasin. Sebagai pusat kota, kecamatan Banjarmasin Tengah berpenduduk cukup padat, kepadatan paling tertinggi terdapat di Kelurahan Kelayan Timur, dan kepadatan penduduk terendah berada di Kelurahan Kertak Baru Ulu. Potensi yang paling menonjol dari kecamatan ini ialah sektor perdagangan. Hal ini dapat dilihat dari banyaknya pasar (42 pasar tradisional dan 3 pusat perbelanjaan modern).

Karena merupakan bagian dari kawasan yang terpadat, sejak dulu kecamatan ini masuk dalam kawasan pemukiman kumuh dengan tingkat kriminalitas yang tinggi dan rumah-rumah penduduk yang sangat berdekatan menyebabkan rawan terjadinya kebakaran secara massal. Sebelum menjadi sebuah kecamatan, Banjarmsin Tengah merupakan kecamatan pembantu yang diresmikan pada 28 Februari 1986 oleh Kepala Daerah Tingkat II Banjarmasin. Pembentukan kecamatan ini merupakan realisasi dari Surat Keputusan Gubernur Kepala Daerah Tingkat I Kalimantan Selatan Nomor: 0355 Tahun $1984 .{ }^{17}$

Wilayah Kecamatan Banjarmasin Tengah pusat-pusat ekonomi karena disana terdapat pasar-pasar dan pusat perbelanjaan. Sehingga mayoritas penduduk kecamatan ini pekerjaannya adalah sebagai pedagang. Kecamatan ini dihuni oleh mayoritas etnis Madura dan sebagiannya lagi adalah orang Banjar. Mereka biasanya bermukim di daerah seperti Kampung Kelayan yang dekat dengan Mitra Plaza.

\section{Situasi Kota Banjarmasin Pra Konflik}

Kota Banjarmasin merupakan kota yang dalam masa pertumbuhan ekonomi ketika kerusuhan belum terjadi. Jika dilihat dari statistik ekonomi

${ }^{17}$ Pekik Nursasongko, Atlas Tematik: Kota Banjarmasin (Klaten: PT Intan Prawira, 2011), 16. 
tahun 1997, masyarakat Kalimantan Selatan memang tergolong masyarakat yang makmur. Daya beli masyarakat provinsi ini berada di peringkat ke-5 di tingkat nasional (1. Jakarta, 2. Riau, 3. Bali dan 4. Kalimantan Timur). Tetapi terdapat kesenjangan kehidupan yang cukup mencolok antara si kaya dan si miskin. Urbanisasi yang begitu tinggi membuat kota-kota dipadati oleh manusia. Sepertiga dari penduduk Kalimantan Selatan bahkan tertumpuk di dua daerah, yaitu Kabupaten Banjar dan Kotamadya Banjarmasin. Kemiskinan dan pengangguran menjadi hal yang biasa kita temukan di Kota Banjarmasin. Anak-anak muda yang putus sekolah dan frustasi tanpa harapan masa depan, tidak sedikit yang akhirnya menjadi pemabuk dan mudah berkelahi. Rekaman polisi menunjukkan dengan jelas bahwa kebanyakan perusuh adalah anak-anak muda yang tampak gembira, tanpa beban melakukan tindakan-tindakan anarkis tersebut. $^{18}$

Selama pemerintahan Orde Baru, khususnya Kota Banjarmasin yang diketahui tidak pernah tercatat adanya konflik atau kerusuhan massal. Bahkan aksi demonstrasi mahasiswa dan kritikan serta protes terhadap kebijakan pemerintah ketika itu, dari berbagai kalangan baik itu mahasiswa, LSM, buruh dan gerakan berbau rasial ataupun bersifat SARA yang hingga menjadi perhatian nasional hampir tidak pernah ada. Kota Banjarmasin yang dikenal adalah merupakan kota dengan image yang harmoni dan stabil. Jika pun ada kerusuhan, itu hanya bersekala kecil dan sebatas ketegangan saja. Sehingga peristiwa "Jum'at Kelabu" yang terjadi tahun 1997 yang skalanya cukup besar tersebut benar-benar mengejutkan dan meninggalkan stigma buruk di kalangan masyarakat Banjarmasin.

Dari hasil penelitian yang dilakukan oleh Hairus Salim dari YLBHI dalam buku Amuk Banjarmasin mengatakan bahwa jauh sebelum peristiwa kerusuhan itu pecah, Kota Banjarmasin sudah mengalami beberapa masalah serius yang berlarut-larut beberapa diantaranya adalah terjadinya krisis air bersih meskipun kota ini terkenal dengan "kota seribu sungal" dan tingkat terjadinya musibah kebakaran sangat tinggi ${ }^{19}$ khususnya di daerah pemukiman

\footnotetext{
${ }^{18}$ Mujiburrahman, Mengindonesiakan Islam: Representasi dan Ideologi (Yogyakarta: Pustaka Pelajar, 2008), 381.

${ }^{19}$ Menurut Jawa Post sejak awal Januari tahun 1997 hingga pertengahan Juli 1997 ini saja, di Banjarmasin telah terjadi 35 kali kebakaran dengan memusnahkan lebih dari 1. 000 rumah penduduk dan kebakaran ini belum termasuk peristiwa 23 Mei 1997. Jawa Post, "Mengapa Kebakaran Mudah Melanda Kotamadya Banjarmasin", 21 Juli 1997 dalam buku Hairus Salim HS dan Andi Achdian, Amuk Banjarmasin (Jakarta: Yayasan Lembaga Bantuan Hukum Indonesia (YLBHI), 1997), 37.
} 
yang padat penduduk, sehingga kebakaran sudah menjadi rutinitas kota bagi ini. Hal ini kemudian menjadi masalah bukan hanya bagi masyarakat itu sendiri tetapi juga bagi pemerintah daerah setempat. ${ }^{20}$ Bahkan seminggu sebelum terjadinya kerusuhan, di beberapa tempat khususnya daerah Pasar Sudimampir beberapa kali terjadi kebakaran yang cukup membuat panik masyarakat. ${ }^{21}$ Selain itu masyarakat Banjarmasin telah dilanda perasaan was-was akan terjadinya kerusuhan. Puncak perasaan was-was dan khawatir ditunjukkan pada hari Jum'at 03 Januari 1997, seminggu setelah peristiwa Tasikmalaya dan kurang lebih lima bulan sebelum peristiwa "Jum'at Kelabu” itu.

Hari itu tersebar kabar bahwa Banjarmasin akan terjadi demonstrasi besar-besaran, massa dari luar kota datang untuk berunjuk rasa dan sedang menuju Banjarmasin. Sehingga sebagian pertokoan, swalayan, mall tutup dan memberikan perintah kepada para pegawainya untuk pulang, karena tersebar isu bahwa akan menjadi sasaran amuk massa. Selain itu dari kalangan agama minoritas dilanda keresahan yang luar biasa, karena beredar kabar bahwa tempat ibadah mereka akan diserang. Suasana semakin mencekam ketika masyarakat tumpah ruah ke jalan-jalan terutama di sekitar pertokoan yang diisukan akan dihancurkan seperti pertokoan Barata di Sudimampir dan Mitra Plaza. Sedangkan dari pihak keamanan telah berjaga-jaga dari Polda Kalimantan Selatan, Korem, Polresta dan Kodim Banjarmasin yang telah siap siaga di pusat-pusat perbelanjaan dan terutama di pintu gerbang masuk kota. Serta berbagai unit Barisan Pemadam Kebakaran (BPK) ikut bersiaga. Namun, hingga sore hari tidak ada tanda-tanda akan terjadi isu yang beredar tersebut.

Setelah isu kerusuhan tersebut berlalu, kekahwatiran kerusuhan tersebut muncul kembali beberapa bulan kemudian bersamaan dengan masa kampanye berlangsung. Bentuk yel-yel kampanye yang diteriakkan oleh para simpatisan PDI, Golkar dan PPP serta lengkingan knalpot sepeda motor ini sedikit banyaknya mengandung kekahwatiran akan terjadinya kerusuhan. Sepanjang masa kampanye, agar perjalanan mereka (masyarakat) lancar, tidak terganggu dan sekaligus untuk menjaga keamanan diri, mereka perlu memiliki dan memakai 3 atribut partai tersebut sekaligus, terutama ketika jadwal kampanye partai yang bersangkutan akan berlangsung.

Memasuki akhir kampanye, situasi kampanye semakin memanas dan semakin menegang, PDI dan PPP tampil habis-habisan. Puluhan ribu massa kedua OPP tampil bergiliran, Rabu 21 Mei 1997 kampanye PDI putaran

\footnotetext{
${ }^{20}$ Ibid., hlm. 30-37.

${ }^{21}$ Abdullah, wawancara pribadi, Pedagang Pasar Sudimampir, 19 April 2016.
} 
terakhir dan Kamis 22 Mei 1997 untuk PPP. Massa partai berlambang kepala banteng tersebut memenuhi ruas-ruas jalan dan berkeliling kota berpawai ria dengan meneriakkan yel-yel kebesaran PDI. Ketika sedang berpawai sebuah sepeda motor salah seorang simpatisan terbakar di depan Plaza Junjung Buih yang kemudian memacetkan jalan dan merepotkan petugas keamanan serta Satgas PDI. Selama putaran terakhir kampanye PDI berlangsung oleh oknum simpatisan PDI melakukan pengerusakan terhadap atribut OPP lain dan bahkan dengan kasar mereka berusaha menyerang pengguna jalan yang dianggap mengganggu iring-iringan kendaraan kampanye.

Pada 22 Mei 1997 giliran kampanye PPP putaran terakhir juga mengandung tak kalah ketegangan yang luar biasa. Dengan massa yang banyak mereka menghijaukan Banjarmasin dan beraksi lebih berani. Massa berkampanye dengan yel-yel dan berputar-putar di ruas-ruas jalan bahkan sambil merusak tanda gambar dan menurunkan atribut OPP lain. Dan ribuan massa kampanye PPP juga berhenti di Gedung DPD Golkar dan sempat melempari batu. Tidak hanya itu sebagian oknum massa PPP yang menggelar kampanye hingga malam hari, juga dengan beringasnya melempari rumahrumah penduduk yang didepannya berkibar bendera OPP lain. Aparat ketika itu bertindak sigap sehingga aksi pengerusakan yang lebih parah dapat dihindari. ${ }^{22}$ Selain hadirnya simpatisan PPP dari Hulu Sungai dalam kampanye PPP ini pula tampil pula kelompok "Mahasiswa Bintang". Kelompok mahasiswa ini merupakan mahasiswa Fisipol Unlam, STIE, Universitas Islam Kalimantan (Uniska) dan IAIN Antasari, para mahasiswa inilah yang mewarnai kampanye PPP. ${ }^{23}$ Dari penuturan bapak Fathul bahwa ada gabungan pendukung dari para mahasiswa tersebut yang juga dijuluki "Mega Bintang" yang artinya pendukung dari Partai PDI dan PPP yang bergabung menjadi satu. $^{24}$

Setelah berlalunya kampanye putaran terakhir PDI dan PPP situasi masih Kota Banjarmaisn tetap aman, masyarakat sudah merasa lega dan tidak ada kekahwatiran terhadap kemungkinan akan adanya kerusuhan atau hal-hal yang tidak diinginkan. Karena kedua partai yang dianggap mengancam

\footnotetext{
${ }^{22}$ Dinamika Berita, "PDI dan PPP Habis-Habisan”, Jum'at 23 Mei 1997. Lihat juga Banjarmsin Post, "Bakar Motor Warnai Kampaye Terakbir PDI", dan "Hari Ini Berkampanye Simpatik, Golkar Bagikan Hadiah", Jum'at 23 Mei 1997.

${ }^{23}$ Hairus Salim HS dan Andi Achdian, Amuk Banjarmasin, 9-12.

${ }^{24}$ Fathul, wawancara pribadi, Pegawai di Badan Nasional Penanggulangan Bencana (BNPB) Provinsi Kalimantan Selatan, Rabu 11 Mei 2016.
} 
keamanan telah terlewati dan putaran terakhir kampanye Partai Golkar dianggap tidak menjadi hal yang merisaukan masyarakat ketika itu.

Sedangkan ketika putaran terakhir kampanye Partai Golkar digelar pada hari Jum'at, Partai Golkar turut tampil habis-habisan pula. Dengan keyakinan bahwa menurut Kader Partai Golkar, Drs. KH. Adnani Iskandar menyatakan bahwa kemampuan Partai Golkar selama ini untuk kemaslahatan umat telah menarik simpati para ulama dan tokoh agama Islam sehingga mayoritas ulama, terutama di Kalimantan Selatan berada dalam barisan Partai Golkar dan setiap tahunnya dukungan tersebut semakin meningkat. ${ }^{25}$ Menurut Ketua Harian Bappilu Golkar Kotamadya Banjarmasin dr. Zairullah Azhar, "Pada putaran kampaye terakhir ini semua potensi yang dimiliki dari berbagai kekuatan yang ada dikerahkan sehingga diharapkan mampu mengu-ningkan seluruh wilayah Kota Banjarmasin". Zairullah Azhar juga mengatakan pada putaran akhir kampanye ini pihaknya telah menerima sekelompok waria se-kotamadya Banjarmasin yang menyatakan ikut serta mensukseskan kampanye dan juga ratusan anak-anak baru gede $(A B G)$ yang turut bergabung dalam barisan Partai Golkar. Massa PDI ketika kampanye rencananya membagi-bagikan 30 ribu kupon berhadiah dan 10 nasi bungkus serta membentangkan spanduk terpanjang. Spanduk sepanjang 800 meter bertemakan himbauan sukseskan kampanye digelar di sepanjang jalan dalam Kota Banjarmasin sambil berkeliling kota dan akhir kampanye akbar akan digelar di Lapangan Kamboja. ${ }^{26}$

Selain suhu kampanye yang memanas akibat oknum-oknum massa OPP, hal lain yang membuat masyarakat menjadi cemas adalah beredarnya banyak isu dan selembaran gelap. Selembaran gelap tidak jelas tersebut didapatkan oleh jajaran Polri pasca kerusuhan 23 Mei. Isi selembaran gelap tersebuat adalah mengajak masyarakat untuk saling bermusuhan dan melakukan kerusuhan, dengan isi sebelumnya mengungkapkan ketidakberesan kehidupan bermasyarakat, berbangsa dan bernegara selama ini. Berdasarkan data yang didapat di lapangan, ada beberapa versi selembaran yang beredar. Versi pertama berisi seruan untuk tidak memberikan simpatinya pada salah satu OPP, juga berisi tuduhan-tuduhan bahwa pimpinan OPP adalah seorang yang tidak pantas dan tidak baik. Sedangkan versi lain dari selembaran adalah menggunakan alamat salah satu kota di luar Kalimantan, berisi ajakan kepada seluruh masyarakat untuk saling bermusuhan, juga menyebutkan keburukankeburukan agama tertentu, serta meminta kepada penerima selembaran

\footnotetext{
${ }^{25}$ Banjarmasin Post, “Mayoritas Ulama Dukung Golkar”, 23 Mei 1997.

26Dinamika Berita, "Hari Ini Golkar akan Tampil Habis-habisan", Jumat 23 Mei 1997.
} 
tersebut untuk memperbanyak dan menyebarluaskan. Selain itu selembaran tersebut mengancam pembacanya agar tidak melaporkan atau menyerahkan kepada pihak yang berwajib. Jika pembaca menyerahkan selembaran tersebut, maka dikatakan akan menimpa bala dan musibah yang tak terduga. ${ }^{27}$

Semua aktivitas masyarakat berjalan normal pada hari itu, Jum'at 23 Mei 1997 meskipun merupakan jadwal kampanye terakhir Partai Golkar. Namun, semakin hari siang situasi mulai menegangkan hingga menjadi hari paling buruk dan penuh kabut di seluruh pelosok Kota Banjarmasin. Situasi yang begitu mencekam, mengancam dan tidak stabil. Dimana-mana aparat keamanan bersiaga 24 jam. Kota Banjarmasin yang selama ini dikenal sebagai wilayah aman dan dinamis, sebuah wilayah dengan stereotip keberhasilan pembangunan Orde Baru dengan penekanan makna penting stabilitas politik dalam rangka pembangunan, namun tiba-tiba terjadi aksi atau gerakan yang diluar dari bentuk pembangunan. Pakem masyarakat Banjar yang tenang, tidak pernah secara terang-terangan melakukan protes, apalagi perlawanan yang bisa menyebabkan kerusuhan atau bahkan melanggar dan tidak taat terhadap kebijakan-kebijakan negara yang telah dibuat, tidak ada dalam kamus kehidupan masyarakat Banjar kala itu. ${ }^{28}$

Jika dilihat dipermukaan tidak ada tanda-tanda akan adanya kerusuhan besar di kota ini. Dalam konstelasi sejarah politik lokal masyarakat Banjar, sejak Orde Baru tidak ada jawaban yang cukup akurat mengenai mengapa konflik tersebut bisa terjadi. Garis oposisional etnik Banjar nampak sangat jelas bahwa pertimbangan kepentingan ekonomi akan lebih penting dari pada politik. Dengan kata lain bahwa wilayah masyarakat niaga atau perdagangan jika terjadi perusakan sebuah sistem ekonomi akan menyebabkan kerugian besar, sehingga pemeliharaan terhadap ruang lingkup sistem ekonomi semakin kuat. Dalam pandangan ini persepsi masyarakat terhadap politik menjadi kian kabur dan memudar ketika elit lokal merasa telah terakomodasi kepentingannya di pusat kekuasaan. Meskipun elit politik lokal yang berada di pusat belum sepenuhnya memperhatikan kepentingan masyarakat di daerah ini.

Sejak tahun 1980-an, kegelisahan masyarakat telah tampak sangat kuat ketika industri-industri rotan yang semula dikuasai oleh sebagian besar penduduk lokal di daerah Hulu Sungai dan Kota Banjarmasin, kemudian bangkrut karena hadirnya monopoli industri rotan oleh perusahaan besar. Hasil hutan Kalimantan Selatan khususnya selama ini telah selesai menjadi penyedia

\footnotetext{
${ }^{27}$ Banjarmasin Post, "Polda Kalsel Temukan Selebaran Gelap". 26 Mei 1997.

${ }^{28}$ Hairus Salim HS dan Andi Achdian, "Pengantar" Amuk Banjarmasin, xiii.
} 
papan dan perekonomian penduduk setempat, namun pada sisi yang lain hanya ada sebagian kecil penduduk lokal yang dapat direkrut pada perusahaanperusahaan besar yang ada, hal tersebut beralasan bahwa "orang Banjar susah diatur", sehingga sejumlah tenaga dari perusahaan tersebut didatangkan dari daerah lain. Dan kemudian terjadilah kesenjagan antara masyarakat dan perusahan-perusahaan. Yang dahulunya adalah kawasan pertanian dan perkebunan di daerah Hulu Sungai kemudian berubah menjadi kawasan pertambangan. Ketika memasuki tahun 1990-an kekahwatiran masyarakat di daerah ini semakin kuat, ketika perekonomian semakin tidak menentu, persaingan niaga menjadi lebih tajam, angka pengangguran semakin bertambah dan arus pendatang dari luar daerah semakin tidak dapat dibendung. ${ }^{29}$ Yang kemudian menyebabkan semakin banyaknya masalah yang dihadapi oleh kota ini.

\section{Pecahnya Konflik “Jum'at Kelabu”}

Hari Jum'at, 23 Mei 1997 merupakan putaran terakhir dari kampanye Partai Golkar. Menurut rencana setengah hari kampanye diawali dengan kampanye simpatik berupa pendekatan kepada kalangan bawah dengan target operasi buruh, pengojek, dan tukang becak. Kemudian, setengah hari berikutnya selesai ibadah shalat Jum'at baru kampanye akan dilanjutkan dengan panggung hiburan rakyat di lapangan Kamboja. Pada acara tersebut akan hadir Menteri Sekretaris Kabinet (Mensekkab) Saadilah Mursjid, Ketua MUI KH. Hasan Basri, dan artis-artis ibu kota. Rencana itu tidak pernah terwujud, karena yang terjadi kemudian adalah malapetaka berupa kerusuhan massal. ${ }^{30}$

Kegiatan kampanye yang dimulai sekitar pukul 09.00 dan selesai pada pukul 11.00 ini semakin terlihat semarak karena Partai Golkar membagibagikan sapu tangan bergambar beringin, 30 ribu kupon berhadiah dan nasi bungkus, masing-masing berjumlah 10 ribu buah. Sasaran kampanye ini ialah para buruh, tukang becak, tukang ojek. Pada sekitar pukul 12.00 atau tengah hari, umat Islam menjalankan ibadah shalat Jum'at, sesuai rencana awal ketika shalat Jum'at kegiatan kampanye di stop dan dilanjutkan usai shalat. Namun, sewaktu ibadah Jum'at berlangsung, sebagian massa kampanye Partai Golkar yang umumnya terdiri dari anak-anak muda dan remaja, masih berkampanye berputar-putar keliling kota dengan menaiki sepeda motor lengkap dengan

\footnotetext{
${ }^{29}$ Hairus Salim HS dan Andi Achdian,'Pengantar’ Amuk Banjarmasin, xv.

${ }^{30}$ Sulistyo, Hermawan, “Anarki Enam Jam: Rekonstruksi Kerusuban Jumat Membara di Banjarmasin”, dalam Haris Syamsudin, Kecurangan dan Perlawanan Rakyat dalam Pemilihan Umum 1997, (Jakarta: Yayasan Obor Indonesia, 1999), 185.
} 
segala atribut Partai Golkar. Banyak diantara sepeda motor itu knalpotnya dicopot sehingga suara raungan-raungan mesin motor dirasakan sangat mengusik ketenangan para jamaah. Puncaknya, ketika pawai sepeda motor tersebut berkeinginan melewati Masjid Noor ${ }^{31}$ di Jalan Pangeran Samudera.

Perlu diketahui terlebih dahulu, kedudukan kultural dan politik Masjid Noor di tengah masyarakat Banjarmasin. Masjid Noor yang terletak di Jalan P. Samudra yang letaknya tidak jauh dari Pasar Baru ini merupakan masjid yang terkenal dibangun oleh para pedagang Banjar yang juga merupakan wilayah dan basis pendukung PPP. H. Anang Hadrianoor selaku Pimpinan Masjid Noor mengatakan bahwa masjid ini populer dengan masjid yang tak pernah meminta dan menerima sepeser pun bantuan maupun sumbangan dari pemerintah. Hal ini yang kemudian menunjukkan bahwa ada jarak dan indepedensi komunitas masjid ini dengan 'negara'. Masjid Noor ketika itu lebih dari 10 tahun direnovasi dengan hanya mengharap sumbangan dari para jamaah dan dermawan. Dan masjid ini juga sensitif terhadap gerakan-gerakan yang dianggap mengganggu ketertiban dan ketenangan masjid. Beberapa kasus pernah terjadi di masjid ini akibat ketidaksengajaan dari warga etnis Cina mendengarkan radio dengan keras ketika jamaah sedang melakukan ibadah di masjid. ${ }^{32}$

Menurut sumber dari Tim Lembaga Bantuan Hukum Nusantara (LBHN) cabang Banjarmasin yang melakukan investigasi ke lapangan yang juga dibenarkan oleh $\mathrm{H}$. Anang bahwa, ketika massa yang akan berkampanye itu melintas, jamaah shalat Jum'at yang luber sampai ke badan jalan itu masih sedang berdoa. Namun sebagian para simpatisan Partai Golkar yang mengendarai motor meraung-raung sekitar pukul 13.30 tersebut menerobos

\footnotetext{
${ }^{31}$ Menurut sejarah, masjid ini semula merupakan langgar yang didirikan oleh keluarga keturunan Arab yang berkubur di dalam komplek masjid tersebut. Tahun 1953, langgar ini kemudian berubah fungsinya menjadi sebuah masjid untuk memenuhi kebutuhan khususnya shalat Jum'at para pedagang di sekitarnya yang semakin ramainya. Dalam sejarah lainnya pula bahwa masjid ini pernah menjadi basis berkumpulnya pendukung Masjumi. Hingga ketika itu masjid ini juga pernah terjadi keributan antara NU dan Muhammadiyah untuk menguasainya. Masjid yang memiliki dua lantai ini tak begitu luas karena kanan kiri masjid tersebut adalah pertokoan dan disebelah selatan adalah Jalan S. Parman. Jika shalat Jum'at jamaahnya tumpah ruah ke jalan. Sehingga Jalan S. Parman itu ditutup, begitu pula dengan pertokoan di sekitarnya yang diantaranya banyak milik pedagang Cina juga tutup. Dan ini sudah berlangsung lama, serta tidak ada gangguan dan keluhan dari berbagai pihak. Hairus Salim HS dan Andi Achdian, Amuk Banjarmasin, 42.

${ }^{32}$ Hairus Salim HS dan Andi Achdian, Amuk Banjarmasin, 41-42. Dikutip dari H. Anang Hadrianoor, wawancara pribadi, Ketua Pengelola Masjid Noor, Senin 30 Mei 2016.
} 
batas yang dibuat untuk orang-orang yang shalat di badan jalan. Massa kampanye bermaksud menuju Lapangan Kamboja tempat kampanye Partai Golkar dipusatkan dan tidak jauh dari Masjid Noor. Sebenarnya Polantas sudah berusaha menghadang massa yang beringin lewat dan mengarahkan untuk lewat Pasar Lama. Namun, Satgas Golkar bersikeras untuk melewati Jalan P. Samudra tersebut, dengan alasan shalat Jum'at akan usai. ${ }^{33}$

Sejak dulu menurut $H$. Anang sebenarnya masyarakat Kota Banjarmasin telah mengetahui bahwa sekitar jalan Masjid Noor tersebut ketika shalat Jum'at akan ditutup total hingga jembatan Dewi karena para jamaah shalat Jum'at selalu meluber hingga ke jalan bahkan hingga saat ini. Toko-toko milik orang Banjar dan milik etnis Cina juga terpaksa tutup hingga shalat Jum'at usai karena berada di daerah sekitaran Jalan Pangeran Samudra dan Masjid Noor. Namun, mereka memahami dan mengerti sehingga tidak pernah terjadi penolakan ataupun protes dari warga etnis Cina khususnya mereka yang harus terpaksa menutup toko-toko mereka ketika shalat Jum'at sedang berlangsung. ${ }^{34}$

Menurut berbagai sumber tindakan okum massa Partai Golkar tersebut yang kemudian memicu kemarahan jamaah yang masih menjalankan ibadah shalat Jum'at, sehingga setelah keluar dari masjid mereka kemudian merusak berbagai atribut Partai Golkar yang ada. Mereka juga mencegat massa Partai Golkar yang lewat di depan Masjid Noor dan memaksa untuk melepas semua atribut Partai Golkar yang melekat. Sedangkan menurut H. Anang, orang-orang yang mengamuk dan melakukan pengerusakan tersebut bukanlah dari jamaah Masjid Noor apalagi melakukan penjarahan karena para jamaah mayoritas adalah pedangang pasar Sudimampir dan Pasar Ujung Murung.

Peristiwa yang bermula di Masjid Noor itu kemudian menyebar di sebagian kota dan massa berdatangan dari penjuru kota, seperti jamaah Masjid Agung, Masjid Kampung Melayu dan Pasar Lama. Akibat bentrok yang terjadi di Masjid Noor, Satgas Partai Golkar yang terdesak kemudian melarikan diri ke Kantor DPD Partai Golkar Kalimantan Selatan yang berada di Jalan Lambung Mangkurat, sekitar $1 \mathrm{~km}$ dari Masjid Noor. Massa terus mengejar dan terjadi saling melempar batu kedua kubu (massa dan simpatisan Partai Golkar). Akhirnya simpatisan dan Satgas Partai Golkar, yang rata-rata berasal dari

\footnotetext{
${ }^{33} \mathrm{Ibid}$, hlm. 42-43. Dan H. Anang Hadrianoor, wawancara pribadi, Ketua Pengelola Masjid Noor, Senin 30 Mei 2016. Lihat Juga https://www. facebook. com/Family-Bpfc220038458182708/. Diakses pada 23 Mei 2016.

${ }^{34} \mathrm{H}$. Anang Hadrianoor, wawancara pribadi, Ketua Pengelola Masjid Noor, Senin, 30 Mei 2016.
} 
organisasi Pemuda Pancasila dan FKPPI ini melarikan diri. Karena massa terlalu banyak kemudian membakar lima mobil peserta kampanye Partai Golkar. Setelah massa membakar mobil, kini giliran massa membakar bagian depan Kantor DPD Partai Golkar tersebut beserta hadiah-hadiah yang akan dibagikan ketika penutupan kampanye. Massa mengambil alih kantor tersebut dengan menurunkan bendera Partai Golkar dan menggantinya dengan menaikkan bendera hijau. ${ }^{35}$

Dari hasil evakuasi yang dilakukan, jumlah korban yang tewas dan kerusakan dalam peristiwa tersebut masih kontroversi hingga sekarang. Karena untuk korban yang tewas terbakar sangat sulit dikenali dan diidentifikasi dan sisanya dinyatakan hilang. Hanya ada tulang belulang yang berserakan di dalam Mitra Plaza yang masih tersisa. Informasi jumlah korban didapatkan dari berbagai media dan kepolisian. ${ }^{36}$

Tabel Jumlah Korban Manusia dalam Konflik 23 Mei 1997

\begin{tabular}{|c|c|c|}
\hline No & Jumlah & Keterangan \\
\hline 1 & 123 orang tewas & $\begin{array}{l}\text { Dari data korban menurut versi kepolisian, } \\
\text { ditemukan } 121 \text { korban tewas yang tersebar } \\
\text { dibeberapa tempat yaitu di Siola Inti Mitra, Mitra } \\
\text { Plaza, dan } 2 \text { korban lainnya ditemukan di Swalayan } \\
\text { Srikaya. Dari jumlah tersebut hanya ada } 3 \text { orang } \\
\text { korban yang dapat diidentifikasi. Sedangkan } \\
\text { korban tewas versi keamanan menyebut } 142 \text { orang, } \\
\text { sedangkan versi pers ada yang menyebutnya 136, } \\
133,142,155,156 \text { dan } 170 \text { orang. Hal ini terjadi } \\
\text { dimungkinkan karena adanya perbedaan jumlah } \\
\text { dalam penghitungan kerangka korban serta } \\
\text { tambahan dari korban kerusuhan diluar dari yang } \\
\text { tewas karena terbakar. }\end{array}$ \\
\hline 2 & $\begin{array}{l}118 \text { orang luka- } \\
\text { luka }\end{array}$ & $\begin{array}{l}\text { Jumlah ini di identifikasi dari korban hidup yang } \\
\text { berobat diberbagai rumah sakit. Jumlah ini }\end{array}$ \\
\hline
\end{tabular}

\footnotetext{
${ }^{35}$ Hairus Salim HS dan Andi Achdian, Amuk Banjarmasin, 51.

${ }^{36}$ Dinamika Berita, "Korban Tewas Jadi 135 orang, 164 Warga Hilang, 181 Masib Diamankan", 26 Mei 1997, "Korban Tewas Sudab 142 Orang”, "Tidak ada Korban Penembakan” , "Kasus Orang Hilang dalam Peristiwa 23 Mei”. Dan Banjarmasin Post, "Dalam Peristiwa 23 Mei, Masih 197 Orang Hilang Belum Ditemukan", "Komnas HAM Belum Terima Laporan", "Sebagian yang Hilang Sudah Pulang Ke Rumah”, 10-11 Juni 1997.
} 


\begin{tabular}{|l|l|l|}
\hline & & $\begin{array}{l}\text { kemungkinan belum termasuk mereka yang } \\
\text { berobat namun tidak menginap dan langsung } \\
\text { pulang tanpa tercatat dalam administrasi serta para } \\
\text { korban yang tidak berobat sama sekali. }\end{array}$ \\
\hline 3 & $\begin{array}{l}\text { 179 } \\
\text { dinyatakan hilang }\end{array}$ & $\begin{array}{l}\text { Kemungkinan jumlah tersebut telah masuk dalam } \\
\text { jumlah korban yang tewas terbakar. Dan } \\
\text { kemungkinan lainnya adalah mereka yang berusaha } \\
\text { menyelamatkan diri dengan menyeberangi sungai } \\
\text { namun tenggelam, yang tewas ditembak atau } \\
\text { dibunuh dan mayatnya kemungkinan dibuang ke } \\
\text { laut. Sehingga tidak masuk dalam catatan korban } \\
\text { terbakar. Dan sebagiannya lagi adalah } \\
\text { dimungkinkan banyaknya mereka yang kehilangan } \\
\text { anggota keluarga tapi tidak berani melapor. }\end{array}$ \\
\hline
\end{tabular}

\section{Tabel Jumlah Kerusakan Bangunan dan Barang Akibat Kerusuhaan/Konflik}

\begin{tabular}{|l|l|l|}
\hline No & $\begin{array}{l}\text { Jenis Bangunan dan } \\
\text { Barang }\end{array}$ & Keterangan \\
\hline 1 & 5 pusat & $\begin{array}{l}\text { 4 hangus terbakar dan 1 dirusak serta } \\
\text { dijarah }\end{array}$ \\
\hline 2 & 3 sarana pendidikan & $\begin{array}{l}\text { Rusak } \\
\text { dirusak serta dijarah, sedangkan } \\
\text { menurut LBHN yang dihancurkan }\end{array}$ \\
\hline 3 & 11 Gereja & $\begin{array}{l}\text { Menurut LBHN ada 1 dibakar dan } \\
\text { dijarah yaitu Bank Lippo serta data } \\
\text { lainnya ada 4 yang dirusak }\end{array}$ \\
\hline 4 & 5 bank & 1 dibakar dan sisanya dirusak \\
\hline 5 & 3 Vihara & Dirusak \\
\hline 6 & 1 Klenteng & Dirusak \\
\hline 7 & 1 Panti Jompo & Terbakar \\
\hline 8 & 1 Apotek & $\begin{array}{l}\text { 1 dibakar Hotel Arum (Kalimantan) dan } \\
\text { Hotel Barito dirusak }\end{array}$ \\
\hline 9 & 2 Hotel & Sengaja dibakar dan ikut terbakar \\
\hline 10 & 151 rumah penduduk & 1 dibakar dan sisanya dirusak \\
\hline 11 & 5 ruko & \\
\hline & &
\end{tabular}




\begin{tabular}{|l|l|l|}
\hline 12 & 2 kantor swasta & Sengaja dibakar dan terbakar \\
\hline 13 & 144 toko & $\begin{array}{l}\text { Dirusak dan terbakar ini tersebar di } \\
\text { beberapa tempat }\end{array}$ \\
\hline 14 & 36 mobil & 20 dibakar dan sisanya rusak berat \\
\hline 15 & 1 truk & Dibakar \\
\hline 16 & 47 sepeda motor & 36 dibakar dan 11 rusak berat \\
\hline 17 & 9 sepeda & Terbakar \\
\hline 18 & 151 rumah makan & Terbakar \\
\hline
\end{tabular}

Setelah semua korban tewas yang ditemukan ada sekitar 120 mayat tersebut kemudian disemayangkan di Rumah Sakit Ulin. Dengan dibantu oleh Dinas Kebersihan dan Pertamanan Kotamadya Banjarmasin mayat-mayat tersebut diberangkatkan dengan 5 mobil jenazah dan dimakamkan massal pada hari Sabtu sekitar pukul 17.00 di Tempat Pemakaman Umum (TPU) milik Pemda Kotamadya Banjarmasin di Jalan Bumi Selamat, KM. 22 Kecamatan Landasan Ulin, Kabupaten Banjar. Jarak antara lokasi kejadian dan penguburan massal kurang lebih ditempuh dalam waktu 30 menit dengan menggunakan sepeda motor.

Sehari sebelum pemakaman, 3 jenazah yang masih dapat teridentifikasi, diambil oleh keluarga korban dan sisanya dimakamkan secara massal. Para korban kerusuhan tersebut dimakamkan secara Islam dan adat. Jenazahjenazah dimandikan, dikafani dan dishalatkan di kamar jenazah sebelum dimakamkan. Dua diantara jenazah tersebut menggunakan peti dan sisanya menggunakan kain kafan. Setelah dimakamkan dilakukan tahlilan selama 3 hari.

Dari jumlah data yang dihimpun dari sejumlah sumber, terdapat perbedaan jumlah korban dan kerugian materi dari kerusuhan 23 Mei tersebut. Tidak ada data yang dianggap paling akurat atau valid yang menyebabkan jumlah korban tersebut tidak sepenuhnya benar. Dan rincian diatas sifatnya hanya besaran dan belum mencakup dampak-dampak yang ditimbulkan dari kerusuhan tersebut seperti hilangnya pekerjaan, mitra pendidikan, trauma psikologis dan lainnya yang tidak termasuk dalam rincian data tersebut. Dari sekian tempat terjadinya kerusuhan, namun ada 2 titik pusat kerusuhan terparah yang menelan banyak korban yaitu Mitra Plaza dan kawasan perbelanjaan di Jalan Lambung Mangkurat.

Selain jumlah korban yang belum jelas, cara kematian juga menjadi kontroversi yang hingga sekarang masih menjadi teka-teki. Salah satu yang terlihat jelas ketika dilakukannya evakuasi adalah mayat-mayat yang terbakar itu 
posisinya seperti tertumpuk di bagian depan toko bukan di pintu keluar. ${ }^{37}$ Selain itu pula kejaggalan lainnya adalah Mitra Plaza yang terdiri dari empat lantai dengan sejumlah pertokoan mewah. Namun para korban tewas terbakar dan terkurung hanya di satu toko saja. Karena jika memang mereka adalah penjarah maka, tidak mungkin mereka hanya berada di satu toko saja, apalagi toko pakaian. Sebab lantai I dan III Mitra Plaza justru berisi barang-barang yang lebih berharga dan menggiurkan untuk dijarah. ${ }^{38}$ Ini merupakan beberapa kejanggalan yang terjadi pada kerusuhan di Banjarmasin tahun 1997 yang belum ada kejelasannya.

Ada beberapa istilah penyebutan terhadap peristiwa kerusuhan 23 Mei tahun 1997 di Banjarmasin ini. Sebagian masyarakat ada yang menyebutnya dengan "Kerusuban Banjarmasin", "Amuk Banjarmasin", "Banjarmasin Membara" dan "Jum'at Membara". Namun yang lebih populer disebut oleh kalangan masyarakat adalah "Kerusuban Jum'at Kelabu". Yang mana telah dijelaskan sebelumnya bahwa kerusuhan ini terjadi tepat pada hari Jum'at.

\section{Penyebab Konflik 23 Mei 1997}

\section{Rute Kampanye}

Tanggal 23 Mei 1997 hari Jum'at rute kampanye Partai Golkar dimulai di Kantor DPD Partai Golkar jalan Lambung Mangkurat. Ketika hendak melewati Masjid Noor yang saat itu sedang melaksanakan shalat Jum'at hingga ke badan jalan berada tepat di jalan P. Samudra massa kampanye yang telah berkeliling kota tersebut telah diberikan jalur alternatif oleh petugas keamanan melalui Pasar Lama untuk sampai ke Lapangan Kamboja tempat dimana penutupan kampanye akan digelar. Namun, 3 Satgas Golkar memaksa masuk dan menerobos kerumunan jamaah yang belum selesai melaksanakan ibadah shalat Jum'at.

\section{a. Basis Partai}

Bagi orang Banjar, perpolitikan bukalah suatu prioritas bagi kehidupan keseharian mereka. Masyarakat Banjar lebih dikenal sebagai pedangang yang handal. Banjarmasin hampir tidak pernah terjadi pergolakan politik yang signifikan. Gubernur Gusti Aman mengatakan bahwa sudah puluhan tahun sejak 1966 hingga 1997 tidak pernah terjadi kerusuhan di Banjarmasin.

Kerusuhan Jum'at Kelabu dipicu oleh isu politik, mengingat kerusuhan ini terjadi di tengah euforia Pemilu 1997. Kompas, 24 Mei 1997 memberitakan

\footnotetext{
${ }^{37}$ Fathul, wawancara pribadi, Pegawai BNPB, 11 Mei 2016.

${ }^{38}$ Hairus Salim HS dan Andi Achdian, Amuk Banjarmasin, 67-68.
} 
bahwa banyak orang yang mengacungkan angka 2 dibalas dengan angka 1 pada pagi hari sampai menjelang shalat Jum'at sehingga mengundang kejengkelan masyarakat.

Basis Partai di wilayah Banjarmasin ketika itu sebenarnya adalah PPP (NU dan Masyumi), namun Partai Golkar ketika itu menguasai dengan cara yang kurang baik, mendapatkan perlakuan istimewa dan pada saat itu seluruh pegawai negeri atau PNS diwajibkan memilih Partai Golkar ketika Pemilu. ${ }^{39}$ Kejengkelan masyarakat terhadap Golongan Karya (bukan Partai Golkar) terakumulasi pada kerusuhan ini. Partai Golkar dinilai sangat mendominasi kehidupan masyarakat sehingga keberadaan partai lain dikesampingkan. Akibatnya, orang-orang yang tidak suka dengan Partai Golkar memprovokasi massa untuk bertindak anarkis

\section{b. Tidak Menghormati Ibadah Shalat Jum'at}

Konflik "Jum'at Kelabu" juga diperkuat oleh unsur agama. Dasar dari argumen tersebut adalah adanya sekelompok oknum berbaju kuning (Golkar) yang memprovokasi massa dengan tidak shalat Jum'at dan konvoi keliling kota sambil membunyikan motor dengan keras sehingga mengganggu masyarakat. Mereka melintasi beberapa masjid, termasuk masjid Noor di jalan Pangeran Samudera. Dan memaksa menerobos jalan yang sedang digunakan untuk shalat Jum'at. Hal ini memperlihatkan tidak adanya penghormatan dan penghargaan kepada jamaah shalat yang luber hingga ke badan jalan.

\section{c. Agresifitas Massa Peserta Kampanye}

Konflik "Jum'at Kelabu" ini juga merupakan imbas dari memanasnya suhu politik nasional pada waktu itu. Sebelum terjadi Jum'at Kelabu, terjadi beberapa kerusuhan di beberapa kota lain. Agresivitas massa para peserta kampanye semakin memanas. Himbauan dari pejabat pemerintah dan aparat keamanan tidak mampu mengurangi kebringasan massa. Khususnya di Kota Banjarmasin pada kampanye putaran terakhir yang dilakukan ketiga OPP setidaknya ada beberapa insiden yang terjadi seperti, sebuah sepeda motor dibakar, seorang aktivis mengatakan bahwa adegan motor terbakar itu adalah sebuah provokasi. Mereka juga merusak atribut OPP lain dan tak segan melukai orang-orang yang menghalangi iringan kendaraan kampanye, mereka melempari rumah-rumah warga dan kantor DPD Partai Golkar, mencopot serta merusak atribut-atribut OPP lain ketika kampanye. Selain itu yel-yel yang diteriakkan oleh ketiga OPP dan suara knalpot sepeda motor yang sangat keras bahkan, sebagian dari mereka ada yang sengaja merusak atribut-atribut partai

\footnotetext{
${ }^{39}$ Maimunah, wawancara pribadi, masyarakat, Kamis 28 Juli 2016.
} 
lain ketika berkampanye. Kejadian-kejadian diatas merupakan bentuk agresivitas massa para peserta kampanye.

\section{Peran Non Govermental Actor dan Usaha Peace Building Pasca Konflik Tahun 1997 di Banjarmasin}

Konflik yang terjadi di Kota Banjarmasin telah menimbulkan banyak masalah sosial yang tidak hanya dirasakan oleh warga asli Banjar tetapi juga warga dari etnis Cina serta umat beragama lainnya yang toko dan tempat ibadahnya menjadi korban. Jika kita melihat konflik atau kerusuhan yang terjadi di Banjarmasin maka sangat jelas bahwa konflik yang terjadi termasuk dalam kategori konflik sosial bernuansa agama meskipun lebih dominan bernuansa politik. Namun demikian nuansa agama tidak dapat di kesampingkan begitu saja karena dilibatkannya simbol-simbol agama dalam tragedi tersebut. Selain aspek-aspek sosial dan ekonomi ikut berperan pula di dalamnya. ${ }^{40}$

Tragedi kerusuhan yang terjadi menjelang berakhirnya masa Orde Baru tersebut, merupakan hal yang lumrah terjadi karena konflik merupakan gejala sosial dan memori sejarah akan kejadian tersebut akan terus menerus ada. Dari peristiwa tersebut kita dapat melihat berbagai bentuk penyelesaian konflik yang dilakukan selama ini. Penyelesaian konflik dapat dilakukan dengan dua cara yaitu: model penyelesaian konflik dengan kekerasan dan model penyelesaian konflik dengan perdamaian atau damai.

Ketika konflik 23 Mei 1997 masih hangat terjadi, model penyelesaian yang tepat digunakan adalah dengan tindak kekerasan ${ }^{41}$ melalui pihak-pihak yang berwajib untuk menjaga keamanan, militer dan Pangdam serta masyarakat yang bersiaga 24 jam ketika jam malam masih diberlakukan. Tujuannya adalah untuk meredam konflik yang berkecamuk dan memberikan rasa aman kepada masyarakat. Cara ini telah terbukti bahwa untuk menyelesaikan suatu konflik dapat pula dengan menggunakan konflik baru yaitu kekerasan yang sama.

Ketika itu model penyelesaian konflik dengan kekerasan memang dianggap tepat dan solusi paling efektif dalam meredam konflik. Meskipun mereka yang menjadi korban di lokasi kejadian itu belum tentu semuanya

\footnotetext{
${ }^{40}$ M. Baharudin, "Filsafat Perenial Sebagai Alternatif Metode Resolusi Konflik di Indonesia", Jurnal Teologia, Volume 25, Nomor 1, (Januari-Juni 2014), 12.

${ }^{41}$ Diceritakan oleh sebagian saksi mata, para pihak keamanan dengan brutal menembak dan membunuh orang-orang yang dianggap perusuh dan penjarah di lokasi kejadian karena sebagian besar massa tidak ingin menyerah dan semakin brutal serta memblokade daerahdaerah tertentu sehingga massa terkepung.
} 
adalah penjarah dan perusuh. ${ }^{42}$ Karena dari sebagian keluarga korban mengatakan bahwa anak, suami atau saudara mereka yang hilang itu hanya berniat untuk melihat kejadian dan mencari anak mereka, namun hingga kini mereka tak kembali. ${ }^{43}$

Selanjutnya model penyelesaian konflik dengan perdamaian juga dilakukan ketika kerusuhan mulai mereda, dapat ditangani dan sudah dapat dikendalikan. Pihak pemerintah mengumpulkan dan melakukan pertemuan dengan gubernur, pihak-pihak keamanan (Pangdam, Kapolda), tokoh-tokoh agama, tokoh-tokoh adat, ke tiga OPP, LSM, mahasiswa dan masyarakat umum untuk mencari solusi perdamaian dan menstabilkan keadaan yang telah terlanjur kacau tersebut. Upaya ini diharapkan terbentuknya komunikasi untuk membuka peluang negosiasi antara pihak yang berkonflik untuk mencapai suatu kesepakatan. Selain itu dilakukan pula kunjungan kepada para korban yang dirawat di rumah sakit dan memberikan bantuan moral dan materil kepada keluarga korban kerusuhan. ${ }^{44}$

Dalam hal ini semua elemen-elemen masyarakat (non govermental actor) dikerahkan untuk sama-sama membangun damai (Peace Building). Ini merupakan salah satu tindakan yang dianggap tepat ketika situasi masih memanas pasca kerusuhan. Lain halnya dengan masa sekarang ini, ketika kerusuhan sudah berlalu begitu lama, dari beberapa pihak masih melakukan upaya-upaya membangun damai sebagai bentuk resolusi konflik. Usaha ini dianggap penting untuk mencegah konflik serupa atau konflik yang berbeda terjadi lagi. Seperti, yang dilakukan elemen-elemen masyarakat Kota Banjarmasin, dengan mengulang dan menghadirkan kembali memori kolektif kerusuhan pada masa kini, diharapkan masyarakat dapat mengingat kembali perihnya rasa sakit, kehilangan, kekerasan, penjarahan dan pengerusakan yang dulu banyak memakan korban jiwa. Sehingga tertanam harapan besar bahwa kejadian serupa tidak akan terulang kembali.

Melalui aksi menolak lupa dan mengenang tragedi tersebut, masyarakat dapat mengambil hikmah dan pelajaran, bahwa emosi yang dihadirkan secara besar kepermukaan hanya akan membawa dampak negatif dan kerusakan. Namun, dari aksi-aksi mengenang kembali peristiwa kerusuhan "Jum'at Kelabu" di ruang publik, selain membawa dampak positif untuk peace building pasca

\footnotetext{
42Banjarmasin Post, “Komnas HAM: Belum Tentu yang Tewas Perusub”, 2 Juni 1997.

${ }^{43}$ Nur Hayati dan Jambrut, wawancara pribadi, keluarga korban, 22 dan 30 Mei 2016.

${ }^{44}$ Pandita Sharwa Dharma, wawancara pribadi, Tokoh Agama Buddha, 22 Mei 2016. Lihat juga Laporan Hasil Pemantauan Kasus Kerusuhan Banjarmasin Komnas HAM Tahun 1997.
} 
kerusuhan. Selain itu dapat pula membawa pengaruh dan dampak negatif bagi psikologis masyarakat Kota Banjarmasin. Karena dari aksi tersebut akan membuka kembali luka lama (memori kolektif) terutama bagi keluarga korban kerusuhan, dengan membangkitkan kembali emosi, amarah, kecewa dan sedih. Hal tersebut yang kemudian dapat menanamkan kembali kebencian terhadap partai, agama, etnis dan pemerintah yang dianggap lalai dan tidak pernah tuntas menyelesaikan kasus ini hingga sekarang. Hal ini terlihat ketika wawancara dengan keluarga korban kerusuhan, mereka bercerita dengan bercucuran air mata, mengingat kejadian hilangnya anggota keluarga mereka tanpa kabar yang jelas. Selain itu mobilisasi massa dalam aksi dapat menimbulkan masalah baru, bentrok dengan aparat keamanan ataupun warga yang perjalanannya terganggu karena aktivitas tersebut dilakukan di tengah jalan raya yang dalam kondisi lalu lintas padat.

Meskipun demikian model penyelesaian konflik secara damai tersebut lebih relevan dan juga sesuai dengan prinsip-prinsip kemanusiaan, keadilan dan HAM, sesuai dengan Pancasila dan UUD yang berlaku di Indonesia. Sehingga dari konflik yang terjadi di Banjarmasin dan daerah lainnya di Indonesia, pemerintah dan masyarakat dapat menggunakan model peace building yang lebih beradab ketika menghadapi konflik saat ini.

Dari pemantauan yang dilakukan oleh Tim Komnas HAM, ditemukan beberapa pelanggaran HAM sebagai berikut:

1. Freedom From Fear

Akibat peristiwa tersebut telah menimbulkan ketakutan yang besar di masyarakat Kota Banjarmasin. Ketakutan di perparah dengan beredarnya berbagai desas-desus akan muncul kembali kerusuhan baru dan upaya balas dendam dari pihak yang merasa dirugikan.

2. Right to Property

Pembakaran dan perusakan bangunan, kendaraan milik anggota masyarakat selama kerusuhan, merupakan pelanggaran terhadap hak atas harta benda.

\section{Freedom of Religion}

Gangguan terhadap umat yang sedang menjalankan ibadah shalat Jum'at merupakan pelanggaran HAM (freedom for worship). Pembakaran dan perusakan gereja, vihara dan bangunan yang berhubungan dengan agama (sekolah, rumah jompo) merupakan pelanggaran terhadap kebebasan beragama.

4. Right of Dignity 
Adanya pemaksaan untuk membuka baju di depan umum, khususnya kaum perempuan merupakan pelecehan terhadap kehormatan seseorang yang tak dapat diterima.

5. Right to Live

Serangan massa terhadap sembarangan orang yang dianggap bukan kelompoknya, telah menimbulkan beberapa orang mengalami luka berat. Begitu pula dengan penyiksaan terhadap tahanan yang diduga terlibat kerusuhan merupakan pelanggaran atas hak hidup.

6. Presumption of Innocense

Cara-cara penangkapan dan penahanan yang dilakukan oleh aparat keamanan belum sepenuhnya sesuai dengan KUHP. Khususnya atas 5 orang mahasiswa dari UNISKA dan STIE perlu mendapat perhatian khusus, karena tidak ditemukannya bukti-bukti yang cukup, kecuali adanya pengakuan bahwa mereka melakukan rapat tanggal 22 Mei untuk menaggalkan kampanye Partai Golkar. ${ }^{45}$

\section{Bentuk Memori Kolektif dari Non Governmental Actor Pasca Konflik di Ruang Publik}

Ilmu-ilmu manusia (bumanities) dan filsafat tradisional cenderung memandang ingatan sebagai konsep yang sifatnya individual. Artinya hanya individu-lah yang bisa mengingat. Namun menurut Halbwachs isi dan cara individu mengingat jauh lebih dipengaruhi oleh realitas sosial dari pada oleh individu itu sendiri. Inilah pengandaian dasar psikologi kolektif yang dirumuskan oleh Halbwachs. Baginya untuk memahami motif, aspirasi, emosi, dan pengalaman-pengalaman subjektif manusia, orang harus mampu mengaitkan aspek-aspek manusiawi itu dengan realitas sosial. Realitas sosial yang menjadi latarbelakang sekaligus penentu isi dari kesadaran ataupun ingatan individual. ${ }^{46}$

Halbwachs mengatakan dengan jelas bahwa ingatan kolektif bukan hanya merupakan gabungan ingatan-ingatan lama tentang yang sudah berlalu, tetapi juga hakikat dari kelompok tersebut. Di dalamnya juga tercakup harapan akan masa depan. Implikasi adalah walaupun generasi berakhir, orang meninggal dan tempat berubah, namun ingatan kolektif akan terus lestari dan ditafsirkan terus menerus untuk menanggapi jaman yang berubah. 'Ingatan

\footnotetext{
${ }^{45}$ Banjarmasin Post "Komnas HAM Catat 6 Pelanggaran", Mei 1997.

${ }^{46}$ Reza A. A Wattinema, Indonesia, Nasionalisme dan Ingatan Kolektif: mengembangkan Nasionalisme Indonesia Melalui Penegasan Ingatan Kolektif (Melintas, 2009), 242-243. Pdf.
} 
kolektif' atau 'memori kolektif' menurut Halbwachs menyesuaikan diri dengan gambaran dari fakta-fakta lama pada kepercayaan dan kebutuhan spiritual saat ini.

Halbwachs dengan tegas menyatakan bahwa, ingatan kolektif bukanlah cerminan masa lampau yang akurat, melainkan sebuah representasi kebutuhan masa kini dan harapan akan masa depan. Ingatan kolektif dapat dengan mudah melepaskan ingatan akan peristiwa, jika peristiwa tersebut dipandang merugikan masa kini dan membunuh harapan akan masa depan yang lebih baik. Dan sebaliknya ingatan kolektif dapat dengan mudah menciptakan ingatan baru akan suatu peristiwa, terutama jika peristiwa tersebut mampu memberikan makna pada masa kini dan alasan untuk berharap pada masa yang lebih baik. ${ }^{47}$

Berikut ini adalah uraian singkat dari pemikiran Halbwach tentang memori kolektif:

\section{Memori kolektif dikonstruksi secara sosio-politik}

Memori kolektif tidaklah berarti menghadirkan fakta-fakta otentik masa lalu secara bersama, melainkan salah satu versi masa lalu yang diseleksi untuk diingat oleh kelompok tertentu untuk mencapai tujuan tertentu dan membentuk persepsi diri kelompok tersebut. Memori didefinisikan dan dinegosiasikan dalam lingkungan kekuatan dan agenda politik tertentu.

2. Konstruksi memori kolektif berlangsung terus menerus dan dalam proses multidireksional

Proses membentuk memori kolektif tidaklah linear maupun dalam urutan logis melainkan dinamis dan kontingen (banyak kemungkinan). Peristiwa dan keyakinan hari ini membimbing pembacaan kita atas masa lalu dan pada saat yang sama skema dan kerangka referensi yang dipelajari dari masa lalu membantu memahami hari ini.

3. Memori kolektif bersifat fungsional

Suatu kelompok menggunakan memori kolektif untuk mencapai tujuan-tujuan tertentu misalnya membangun kebersamaan, menentukan mana kawan mana 'the other', bahkan mengenang masa lalu untuk menunjukkan pelajaran moral dari suatu kegagalan.

4. Memori kolektif harus dikonkretkan

Memori kolektif adalah konsep teoretis yang banyak membahas ide-ide abstrak namun untuk membuat konsep fungsional tersebut harus

${ }^{47}$ Ibid, .252-253. 
dikonkretkan dan dimaterialkan melalui struktur fisik dan artefak kultural seperti ritual peringatan (commemorative rituals), monumenmonumen, museum-museum sejarah, dan banyak lagi.

\section{Memori kolektif adalah narasional atau dikisabkan}

Memori haruslah terstruktur dalam pola budaya yang familiar. Pada banyak kasus, memori kultural mewujud pada narasi yang terkenal, dimulai dari permulaan kisah, perkembangan peristiwa, dan akhir cerita, juga ada tokoh protagonis dan antagonis. Lebih dari itu, perujukan ke masa lalu juga melahirkan pelajaran-pelajaran moral yang membimbing dan menunjukkan jalan bagi komunitas yang sekarang. Terlihat dari basis-basis pemikiran Halbwach bahwa memori kolektif berada di tingkat intersubjektif, politis, dan dikomunikasikan secara simbolik dengan menggunakan artefak-artefak (dikonkretkan) atau disampaikan secara verbal (dinarasikan). ${ }^{48}$

Dapat disimpulkan bahwa menurut Halbwachs, ingatan manusia memiliki aspek kolektif. Manusia mengingat dengan simbol, baik dalam bentuk bahasa ataupun simbol-simbol material. Simbol tersebut tidak pernah di bentuk secara personal, melainkan selalu terbentuk dan digunakan secara kolektif. Simbol selalu memiliki makna dan makna merupakan sesuatu yang disepakati. Kesepakatan itu selalu mengandaikan relasi dengan orang lain. Ingatan tidak pernah murni personal, melainkan selalu melalui bahasa atau simbol yang akarnya selalu bersifat kolektif. ${ }^{49}$

Ada berbagai cara dalam menyikapi atau merespon kerusuhan yang pernah terjadi di Banjarmasin. Bentuk-bentuk prilaku yang sebagian elemenelemen masyarakat lakukan adalah bukan dengan menutup rapat memori tersebut, melainkan dengan cara membuka kembali memori yang lama sebagai bentuk kepedulian, resolusi dalam membangun kehidupan lebih damai dan jauh dari konflik apapun.

Kepedulian sosial terhadap sesama yang tertimpa musibah penting untuk dibangun sebagai bentuk solidaritas, karena kita adalah makhluk sosial yang membutuhkan keberadaan orang lain. Tidak perduli apapun latar belakang

\footnotetext{
${ }^{48}$ http://blog.Gilang Desti Parahita, Memori Kultural, Konflik, dan Media, Studi Kasus: Pertikaian Indonesia dan Malaysia atas Iklan "Enigmatic Malaysia". Lihat juga pada Neiger, M., Meyers, O., \& Zandberg, E. (Eds.). (2011). 'Introduction' On media memory: Collective Memory In a New Media age. New York: Palgrave Macmillan.

${ }^{49}$ Reza A. A Wattimena, Indonesia, Nasionalisme dan Ingatan Kolektif: Mengembangkan Nasionalisme Indonesia Melalui Penegasan Ingatan Kolektif., 252. Pdf.
} 
suku, agama dan bahasa. Kita memiliki tanggung jawab untuk sama-sama menjaga dan membangun rasa aman, damai dan tentram. ${ }^{50}$ Richard Hofstadter mengklaim bahwa "memori adalah benang identitas pribadi, dan sejarah identitas publik". 51 Dari perspektif fenomenologis setiap tindakan sosial meresap dengan memori. ${ }^{52}$ Dengan demikian, studi sosiologis memori kolektif menekankan proses memori "kebersamaan" serta kontestasi tentang dan melalui gambar dari masa ke masa. ${ }^{53}$

Diantara bentuk kepedulian dalam membangun kembali semangat dan menjaga perdamaian (Peace Building) secara bersama dapat kita lihat dalam beberapa aksi yang dilakukan dari berbagai kalangan seperti kelompok mahasiswa, LSM, tokoh agama dan organisasi lainnya berupa:

a. Aksi Damai Menolak Lupa Konflik "Jum'at Kelabu"

Menolak lupa atau melawan lupa itulah yang selalu diteriakkan puluhan mahasiswa setiap mengadakan aksi, bahkan tulisan semacam itu tertulis jelas dalam spanduk-spanduk yang mereka bawa. Bukan maksud untuk memprovokasi dan mengungkit-ungkit luka lama, melainkan untuk menjadikan sebuah pembelajaran bagi kita semua agar hal serupa tidak terulang kembali.

Aksi Damai menolak lupa Kerusuhan "Jum'at Kelabu” merupakan agenda rutin tahunan para kelompok mahasiswa dari berbagai perguruan tinggi yang ada di Kota Banjarmasin. Agenda ini telah berlangsung lama hingga sekarang. Setiap tahunnya kelompok-kelompok mahasiswa tersebut melakukan berbagai kegiatan yang bertemakan mengingat kembali tragedi kerusuhan "Jum'at Kelabu" yang terjadi pada 23 Mei 1997. Kegiatan mengenang kembali tragedi berdarah yang pernah terjadi di Kota Banjarmasin "Jum'at Kelabu" ini, Senin 23 Mei 2016, Pukul 09.30 Wita dari puluhan anggota Lingkar Studi Ilmu Sosial Kemasyarakatan (ELSISK) mengadakan aksi damai turun ke jalan yang digelar di simpang empat Jalan Pangeran Antasari (Samping Ramayana) dengan agenda Pembacaan Sejarah dan Puisi "Jum'at Kelabu" disertai teatrikal dan segala atributnya. ${ }^{54}$

Menurut Zainul Muslihin selaku Ketua Umum ELSISK, agenda yang mereka lakukan ini adalah yang pertama kali. Tujuannya adalah untuk

\footnotetext{
${ }^{50}$ Sultan Igo Sanjaya, wawancara pribadi, Anggota BEM Unlam, 15 Juli 2016.

${ }^{51}$ K. Olick Vered Vinitzky, Jefrey dan Seroussi Daniel Levy (ed.),'Pengantar' The Collective Memory Reader. Oxford University Press, 2011, 57.

${ }^{52}$ Ibid., 51.

${ }^{53}$ Ibid., 56.

${ }^{54}$ https://www.facebook.com/Antasaria.Media?fref=nf. Diakses pada Senin 23 Mei 2016.
} 
membangkitkan kembali memori masa lalu untuk mengambil pelajaran dan menolak untuk lupa atas tragedi besar yang telah banyak merenggut korban jiwa tanpa keadilan. Selain itu kegiatan yang mereka lakukan ini merupakan bukti kepedulian sosial terhadap masyarakat yang tentunya akan berdampak positif bagi kedepannya dan berharap kejadian tersebut tidak akan pernah terulang kembali. Saran kepada pemerintahan Kota Banjarmasin khususnya agar lebih perduli terhadap keluarga korban dan keberagaman yang ada di masyarakat karena hal ini sangat mudah memicu konflik baru. Kegiatan aksi mengingat kembali ini sangat penting dimana dari kegiatan ini kita mampu melihat seberapa besar respon dan tanggapan dari masyarakat akan kejadian yang telah lama berlalu ini. Selain agenda turun ke jalan pada pagi hari, agenda lainnya adalah bakti sosial pembersihan makam di pemakaman massal korban 23 Mei 1997 pada sore hari di Jalan Bumi Selamat, A. Yani Km 22 Landasan Ulin, Banjarbaru. ${ }^{55}$

Dari tahun ke tahun, kondisi lokasi kuburan massal yang didalamnya terbaring ratusan mayat tanpa identitas itu kian memprihatinkan. Kondisi kuburan terkadang digenangi air ketika hujan. Patok plang sekitar 60 sentimeter terbuat dari kayu bertuliskan Makam Massal Jum'at Kelabu 23 Mei 1997 sudah mulai kusam. Patok-patok kuburan yang dulunya banyak, kini banyak yang hilang. Hanya tersisa dua sampai tiga patok yang masih berdiri di atas kuburan massal berukuran besar tersebut. Makam kini tersebut menjadi saksi bisu sebuah sejarah peristiwa berdarah di Kalimantan Selatan. Disanalah ratusan koraban terbakar, terbunuh dimakamkan.

Hingga kini tidak ada satu pun pejabat di daerah ini mengujungi pemakaman massal itu. Peneliti atau komnas HAM pun tidak pernah datang ke makam tersebut. ${ }^{56}$ Bahkan dari keluarga korban karena memang tidak diketahui identitas-identitas korban yang dikubur disana. Menurut Shabirin selaku penjaga makam dahulu dari pemilik Mitra Plaza yang terbakar tersebut pernah terlihat beberapa kali datang menziarahi makam massal. Dan di makam massal tersebut sekarang ini ada beberapa batu nisan yang sengaja diletakkan diatasnya secara acak, dimungkinkan bahwa nisan-nisan tersebut sengaja diletakkan oleh

\footnotetext{
${ }^{55}$ Zainul Muslihin, wawancara pribadi, Ketua Umum ELSISK, Minggu 29 Mei 2016. Lihat juga pada http://www.antasaria.com/2016/05/aksi-menolak-lupa-tragedi-23-Mei-1997.html. Diakses pada Senin, 23 Mei 2016.

${ }^{56}$ http://banjarmasin.tribunnews.com/2016/05/23/setelah-19-tahun-tragedi-23-mei-kuburanmassal-itu-kini-mulai-terlupakan. Diakses pada Senin 23 Mei 2016.
} 
keluarga korban dan sisanya rata dengan tanah. ${ }^{57}$ Ketika melakukan survei lapangan yang kedua kalinya tepatnya pada 23 Mei 2016, terlihat diatas makam tersebut taburan kembang yang mulai mengering, itu artinya ada orang yang beberapa hari lalu datang untuk berziarah, kemungkinan itu adalah kunjungan dari keluarga korban.

Sedangkan Rizal dari Sanggar Titian Barantai (STB) Uniska sendiri rutin melakukan aksi teatrikal di sepanjang Jalan Pangeran Samudra, dan pembacaan puisi di depan Mitra Plaza dimana yang dulunya menjadi titik inti kerusuhan tersebut. Bukan karena hanya kerugian fisik, kenangan hitam dan trauma pun masih mencekam masyarakat kota seribu sungai ini, terutama mereka yang kehilangan anggota keluarga.

Kegiatan ini sudah dilakukan sejak tahun 2008 dan menjadi peringatan yang ke 11 bagi warga kota Banjarmasin untuk mengenangnya, tepatnya pada 23 Mei 2008 sejumlah 13 orang anggota Sanggar Titian Berantai (STB) Uniska Banjarmasin menggelar aksi teatrikal di jalan memperingati peristiwa Jum'at Kelabu, 23 Mei 1997. Teatrikal yang mereka adakan tiap tahunnya selalu menampilkan hal-hal yang unik untuk menggambarkan tragedi "Jum'at Kelabu" lengkap dengan segala atribut dan tata rias yang mendukung. Tujuan dari kegiatan ini adalah untuk mengenang dan mendoakan para korban kerusuhan, membagikan bunga mawar kertas dengan secarik kertas berisi harapan dan doa. Kepada Pemerintah mereka berharap kejadian tersebut dapat diusut tuntas dan pemerintah serta pejabat ketika itu tidak tutup mata dan tinggal diam atas kejadian tersebut karena telah menelan banyak korban dan sangat merugikan. Agenda yang STB Uniska lakukan ini berlangsung setiap tahun hingga sekarang. ${ }^{58}$

Selanjutnya dari Persatuan Mahasiswa Islam Indonesia (PMII) Cabang IAIN Antasari Banjarmasin dan PMII Cabang Unlam juga melakukan aksi damai turun ke jalan. Bedanya adalah PMII IAIN mengadakan pada malam hari dengan agenda renungan dan membaca Surah Yasin bersama di Bundaran Post depan Hotel Kalimantan. Sedangkan anggota PMII Cabang Unlam melakukan orasi damai turun ke jalan. ${ }^{59}$

\footnotetext{
${ }^{57}$ Sahbirin, wawancara pribadi, penjaga makam TPU Landasan Ulin, Banjarbaru, 26 April 2016. ${ }^{58}$ Rizal Siddik, wawancara pribadi, Ketua Umum Sanggar Titian Berantai (STB) Uniska Muhammad Arsyad Al-Banjary. 29 Juni 2016.

${ }^{59}$ Riki dan Sultan Igo, wawancara pribadi, anggota PMII dan BEM Unlam,10 Juni dan 15 Juli 2016.
} 
Selain ELSISK dan STB Uniska yang tak pernah ketinggalan mengadakan aksi serupa adalah dari Fisipol Universitas Lambung Mangkurat yang tiap tahunnya mereka mengadakan aksi damai turun kejalan dengan membawa atribut bendera, menyalakan lilin, spanduk yang bertuliskan “Menolak Lupa 23 Mei 1997”, menyanyikan lagu kebangsaan dan kemudian ditutup dengan membaca doa bersama yang ditujukan kepada para korban kerusuhan 23 Mei 1997. Selain itu dalam aksi tersebut ada pula agenda pembacaan sejarah dan puisi, orasi dan sebagainya. Mereka mengajak masyarakat semua untuk kembali mengusut tuntas dan tidak melupakan begitu saja kerusuhan yang terjadi. ${ }^{60}$ Bahkan ketika pasca kerusuhan tepatnya tanggal 29 Mei 1997, dari Senat Mahasiswa Fakultas Hukum Unlam Banjarmasin melakukan bakti sosial mengumpulkan sumbangan di Jalan H. Hasan Basri yang dari hasil sumbangan tersebut dikumpulkan dan dibagikan kepada korban kebakaran di Kelurahan Kertak Baru Ulu, Banjar Barat. ${ }^{61}$

b. Diskusi Lintas Iman

Agenda diskusi ini pernah dilakukan oleh Lembaga Kajian Keislaman dan Kemasyarakatan (LK3). Mereka menaggap penting akan kejadian kerusuhan yang tidak pernah diusut tuntas tersebut. Sehingga dari diskusi tersebut kita belajar mengenai sejarah kelam masa lalu Kota Banjarmasin dan sebagai generasi muda kita dapat membawa kota mereka ke arah yang lebih baik dan positif lewat peran dan kontribusi anak muda sebagai generasi penerus bangsa. Karena LK3 ini tidak hanya merangkul dari satu suku atau agama saja tetapi para anggota dari LK3 ini memiliki latar belakang agama, suku, dan kampus berbeda-beda. Lewat diskusi-diskusi kita membangun solidaritas dan kebersamaan antar umat beragama untuk menciptakan perdamaian di bumi Banjar. LK3 merespon positif kegiatan-kegiatan yang dilakukan mahasiswa maupun LSM untuk mengenang kembali "Jum'at Kelabu". ${ }^{2}$

c. Nonton Bersama Film Dokumenter "Jum'at Kelabu"

Ini merupakan agenda yang berbeda dari tahun-tahun sebelumnya. Tepatnya pada 22 Mei 2015 diadakan nonton bareng film dokumenter "Jum'at Kelabu". Film hasil produksi Photography Conceptual and Cinematography Banjarmasin ini diputar di lantai 2 Gerobak Cokelat Cafe Sultan Adam Banjarmasin pada pukul 20.00 Wita.

\footnotetext{
${ }^{60}$ Sultan Igo Sanjaya, wawancara pribadi, BEM UNLAM HIMA-AP, 25 Mei 2016.

${ }^{61}$ Banjarmasin Post, "Bakti Sosiap”, Kamis 29 Mei 1997.

${ }^{62}$ Dhani, wawancara pribadi, Anggota LK3, 27 April 2016.
} 
Dalam film tersebut menampilkan peristiwa kelam konflik "Jum'at Kelabu" 23 Mei 1997 di Banjarmasin. Kejadian tersebut memang sudah lama berlalu namun peristiwa yang menewaskan ratusan orang itu masih layak untuk dikenang. Acara nobar ini dilaksanakan secara gratis tanpa dipungut biaya. Dan dari pihak panitia penyelenggara menegaskan bahwa pemutaran film dokumenter ini bukan untuk membuka luka lama, namun agar dapat menjadi pelajaran bagi generasi penerus. ${ }^{63}$ Karena antusiasnya para penonton yang membludak, pemutaran film yang hanya dijadwalkan 2 sesi tersebut kemudian panitia menambah menjadi hingga 5 sesi pemutaran. ${ }^{64}$ Kini hampir setiap tahun selalu diadakan nonton bareng film dokumenter tersebut.

d. Program Acara Media Massa

Media massa merupakan alat yang paling cepat dalam menyebarkan berita. Melalui media massa, informasi dari berbagai belahan dunia mampu dinikmati. Namun dari media massa pula dapat menghasilkan berita yang positif dan negatif karena mampu menggiring opini publik. Oleh karena itu, media massa dalam membuat berita haruslah sesuai dengan fakta di lapangan (objektif).

Selain itu media massa juga dapat menyulut konflik, meredam atau bahkan membuka konflik baru melalui berita-berita serta informasi yang mereka tanyangkan. Oleh karena itu media massa harus selektif dalam memilih berita yang akan ditayangkan. Berita yang akan ditanyangkan dituntut bukan hanya sekedar informasi, sarana hiburan tetapi juga mendidik masyarakat secara luas.

Kontribusi TVRI Kalimantan Selatan khususnya dalam perdamaian pasca konflik 23 Mei 1997 di Banjarmasin. Ada berbagai acara yang sengaja dibuat untuk merespon kerusuhan tersebut misalnya, Program Warta Kalsel yang sekarang menjadi Kabar Budaya. Karena informasi-informasi berita yang disampaikan kepada masyarakat jika didengar maka akan tersimpan menjadi memori di alam bawah sadar. Sehingga ketika diawal dan akhir acara diselipkan semboyan atau brand "salam damai banua". Diharapkan dari hal kecil tersebut dapat menanamkan di alam bawah sadar masyarakat bahwa kehidupan itu damai dan motivasi ini sengaja di bangun melalui media tersebut.

\footnotetext{
${ }^{63}$ banjarmasinpost.co.id/istimewa, "Yuk! Nonton Film Dokumenter Jumat Kelabu di Gerobak Coklat”, Jumat, 22 Mei 2015 17:36.

${ }^{64}$ http://banjarmasin.tribunnews.com/2015/05/23/masih-banyak-yang-antre-inginmenyaksikan-film-jumat-kelabu, Sabtu, 23 Mei 2015, 22:16.
} 
Dengan membangkitkan motivasi dan memberi stimulus setiap hari dengan membuat semboyan seperti "banua bisa bangkit dan damai masyarakat agar bangkit" dari kejadian kerusuhan, bencana alam dan lain-lain tentunya akan membawa pikiran positif. Selain program diatas melalui program Acara Forum FKUB yang di tayangkan 2 minggu sekali, diharapkan mampu memberikan stimulus-stimulus yang baik bagi kehidupan umat beragama. Media massa seperti TVRI juga memiliki etika jurnalistik yang telah sepakat dengan segala sesuatu yang berhubungan dengan perdamaian. Sehingga segala isu yang berkaitan dengan SARA tidak boleh ditutupi tetapi harus diberitakan dengan etika yang benar dan sesuai dengan fakta dilapangan sebagaimana kasus kerusuhan "Jum'at Kelabu". 65

Dari semua aksi dan agenda yang dilakukan tersebut diatas sudah menjadi ritual tahunan yang wajib setiap tanggal 23 Mei. Upaya untuk meredam konflik dan menjaga situasi tetap aman pasca konflik dengan cara menghadirkan kembali memori kerusuhan ini sejalan dengan apa yang diungkapan Knight bahwa tujuan utama dari peace building adalah mencegah atau menyelesaikan konflik serta menciptakan situasi damai melalui transformasi kultur kekerasan menjadi kultur damai. Hal ini tentunya dapat dilakukan dengan berbagai cara.

Dalam upaya rehabilitasi dan pencegahan konflik maka Departemen Agama Provinsi Kalimantan Selatan mengadakan dialog antar umat beragama ketika itu. Dalam penyelesaian masalah kerusuhan ini, pemerintah juga dengan sigap melibatkan tokoh-tokoh agama, tokoh-tokoh adat, LSM yang ada di Banjarmasin untuk sama-sama mencari solusi agar masalah kerusuhan yang terjadi ini tidak semakin meluas dan bertambah besar. Peran elemen-elemen masyarakat sangat penting, mengingat tokoh-tokoh agama dan adat merupakan orang-orang yang menjadi panutan bagi masyarakat. Karena dari mereka pula dapat membawa dan melahirkan semangat yang positif ataupun negatif. ${ }^{66}$ Khususnya di Banjarmasin peran seorang Tuan Guru sangatlah besar, jamaah selalu mendengar dan melaksanakan apa yang menjadi petuah dari seorang Tuan Guru. Karena itu seorang ulama atau tokoh agama dituntut untuk bersikap netral. Sebagaimana kabar yang beredar ketika itu bahwa ulama lebih cenderung mendukung Partai Golkar sehingga membawa kekecewaan bagi

\footnotetext{
${ }^{65}$ Saktiono Wahyujati S.Sos, wawancara pribadi, Kepala Seksi TVRI Kalimantan Selatan, 25 Mei 2016.

${ }^{66}$ H. Asnawi Tomas, wawancara pribadi, Ketua DPC PPP Tahun 1997, 4 Juni 2016.
} 
masyarakat. Dari kekecewaan tersebut masyarakat kemudian meluapkannya dengan emosi brutal ketika terjadi kerusuhan.

Bentuk perilaku ini sejalan dengan teori memori kolektif Maurice Halbwachs bahwa penting adanya memori (mengingat dan melupakan) yang menjadi motivasi di balik kehidupan baru yang memiliki peran dan pengaruh yang sangat penting dalam perubahan dan pemulihan pasca konflik. Terdapat hubungan antara diskursus, praktek, ekspektasi sosial yang berubah dan cara individu mengingat masa lalu.

Dalam hal ini, memori masa silam mengenai konflik dari berbagai kalangan yang terlibat dibangun kembali sebagai jalan evaluasi agar konflik yang serupa ataupun yang berbeda tidak terjadi lagi. Karena memori kolektif ini akan tetap ada dan diwariskan dari generasi ke generasi berikutnya, meskipun waktu telah berubah dan tradisi telah menghilang. Oleh karenanya, peran para elemen-elemen masyarakat serta masyarakat secara luas juga memiliki kontribusi yang besar dalam menciptakan memori positif dan perdamaian dimasa depan. Memori kolektif akan konflik tersebut diharapkan dapat berperan sebagai fasilitator perdamaian dalam menyembuhkan luka konflik yang terlajur tergores di hati dan kehidupan masyarakat Kota Banjarmasin.

Memori kerusuhan yang dihadirkan kembali di masa kini jelas akan mengantarkan kembali pada rasa takut, sakit, sedih, kehilangan dan situasi mencekam di Kota Banjarmasin, Maka disinilah kekuatan memori berperan dalam upaya resolusi konflik dan bina damai. Dari rasa takut dan mencekam tersebut masyarakat belajar bahwa kebrutalan-kebrutalan yang terjadi di masa lalu hanyalah berbuah kerugian, kesedihan dan kehancuran dalam berbagai hal, sehingga jangan sampai terulang kembali di masa mendatang.

\section{Pandangan Non Governmental Actor Terhadap Memori Kolektif di Masa Kini}

Banyak upaya yang telah dilakukan dalam rangka penyelesaian konflik yang terjadi pada 23 Mei 1997. Upaya-upaya itu dilakukan sejak konflik masih berkecamuk, pasca konflik (mulai mereda), dan upaya hingga kini untuk menjaga perdamaian. Hal tersebut sudah dirasa maksimal, baik itu dari pihak keamanan yang memburu para penjarah dan perusuh ketika itu, adanya bekerjasama dengan tokoh masyarakat, tokoh agama, tokoh adat serta organisasi yang ada bahkan melibatkan masyarakat secara langsung. Usaha atau upaya ini dipandang penting dan positif untuk terus membangun dan menjaga perdamaian. 
Dalam upaya menjaga perdamaian di masa kini, elemen-elemen masyarakat berupaya menjaga sikap, memperkuat dan menjalin hubungan antar masyarakat yang berbeda keyakinan melalui diskusi lintas iman, dialog dan ramah tamah sebagaimana yang dilakukan oleh LK3 dan juga FKUB. Selain itu aksi nyata semangat perdamaian yang terus dijaga pasca kerusuhan yaitu melalui aksi damai turun ke jalan, pemberitaan dan tanyangan media massa yang positif merupakan hal yang penting pula. Serta pesan-pesan dari tokoh agama yang positif juga merupakan langkah efektif jangka panjang karena masyarakat Kota Banjarmasin sangat fanatik terhadap ke-ulamaan seseorang.

Pandangan elemen masyarakat sendiri mengenai menghadirkan kembali memori kolektif konflik/kerusuhan terbagi menjadi dua kelompok. Kelompok pertama yaitu mendukung adanya usaha menghadirkan kembali memori kerusuhan dan kelompok kedua tidak setuju dengan kegiatan tersebut. Dikarenakan elemen-elemen masyarakat melihat dari berbagai sudut pandang baik itu positif maupun negatif.

\section{Kelompok Mahasiswa dan LSM}

Mahasiswa merupakan kelompok yang aktif dalam menyuarakan perdamaian. Bagi kelompok mahasiswa menghadirkan kembali sejarah kelam kerusuhan itu merupakan upaya mengingatkan kembali masa-masa sulit, sakit dan kacau agar masyarakat Kota Banjarmasin dapat mengambil hikmah dan pelajaran dari apa yang terjadi pada 23 Mei 1997. Aksi yang mereka lakukan tersebut juga telah berkoordinasi dengan pihak keamanaan dan media massa agar kegiatan yang mereka lakukan tetap ranah positif dan dari aksi tersebut dapat disaksikan masyarakat secara keseluruhan baik itu secara langsung ataupun melalui pemberitaan media massa. Dari kegiatan ini melahirkan sikap solidaritas, perduli dan prihatin atas nasib saudara-saudara kita yang menjadi korban terbakar, terbunuh dan bahkan hilang hingga sekarang. Mahasiswa juga mengajak masyarakat turut serta dalam aksi yang mereka lakukan sebagai cara damai menolak segala bentuk kerusuhan apapun latarbelakangnya dan juga mengusut kembali secara tuntas kerusuhan "Jum'at Kelabu".

\section{Media Massa}

Saktiono mengatakan pentingnya peringatan untuk menjaga semangat perdamaian dengan menghilangkan stigma-stigma negatif seputar kerusuhan memang diperlukan. Namun, tidak harus dengan peringatan yang besar turun

${ }^{67}$ Diolah dari wawancara dengan Zainul Muslihin, Sultan Igo Sanjaya dan Rizal Siddik, bulan Mei-Juni 2016. 
ke jalan. Cukup diperingati dengan cara introspeksi dan deklarasi damai bersama saja.

Selain itu, kita tidak perlu menutupi sejarah karena kejadian tersebut merupakan rill adanya dan dapat dijadikan pendidikan bagi masyarakat secara umum. Kini ketika masyarakat semakin kompleks, kemungkinan terjadi lagi kerusuhan serupa sangat berpeluang besar. Karena mulai nampak jelas beberapa kesenjangan yang semakin meningkat, salah satunya adalah pengangguran sehingga kemiskinan dan kriminalitas otomatis ikut meningkat pula.

Dari kejadian kerusuhan "Jum'at Kelabu" TVRI Kalimantan Selatan berusaha meminimalisir terjadinya kerusuhan melalui program-program yang bermanfaat untuk kemajuan masyarakat Kalimantan Selatan seperti acara Kalsel Mapan, Kalsel Pangan dan lain-lain. Saran sekaligus harapan kepada pemerintah yakni perlunya kedewasaan dalam berpolitik yang harus dibangun sejak dini dari pimpinan daerah karena para pimpinan daerah tentunya berasal dari partai politik dan kepada alim ulama Kota Banjarmasin harus bersikap lebih netral serta mengajak umat ke arah menjaga perdamaian. ${ }^{68}$

\section{Tokoh Agama}

Dari tokoh agama sendiri mengajak masyarakat Kota Banjarmasin untuk jangan mudah terprovokasi atas isu-isu atau berita yang beredar yang belum ada kejelasannya. Karena bisa saja oknum-oknum yang tidak bertanggung jawab sengaja ingin mengadu domba serta memecah belah persatuan dan kesatuan di daerah ini. Saling berprasangka yang baik dan berfikir positif merupakan ciri umat yang beragama. Dalam berbagai kesempatan ceramah atau khutbah yang menjadi media dakwah diselipkan ajakan membangun damai, ikut serta secara sportif dalam pemilu, menjaga rasa aman yang telah menjadi tanggung jawab bersama. Sebab keamanan dan rasa damai bukan milik individu tetapi milik semua elemen masyarakat. Hal ini disampaikan ketika menjelang pemilu khususnya dan juga pada kesempatan lainnya. Dari kejadian tersebut masyarakat diajak untuk saling intropeksi diri, saling mendoakan, tidak menyalahkan pihak manapun, menahan amarah, jangan membenci, menjaga perilaku serta membudayakan sifat dan prilaku saling memaafkan dan saling

\footnotetext{
${ }^{68}$ Saktiono Wahyujati, S.Sos, wawancara pribadi, Kepala Seksi TVRI Kalimantan Selatan, 25
} Mei 2016. 
membantu jika ada yang mengalami kesulitan. Semua itu terwujud jika kita mau mengedepankan nilai-nilai moral, sosial dan agama. ${ }^{69}$

Sebagian masyarakat masih trauma akan kejadian kerusuhan tersebut. Sebagaimana survei yang dilakukan Litbang Banjarmasin Post ketika itu membuktikan bahwa adanya gejala trauma dan was-was yang melanda masyarakat. ${ }^{70}$ Terutama keluarga korban yang enggan untuk menceritakan kembali duka kehilangan yang mereka alami. Selain itu ada stigma negatif yang disematkan kepada para korban yaitu perusuh dan penjarah (pencuri) sehingga mereka malu ketika harus mengingat dan menceritakan kembali kerusuhan yang terjadi pada putaran terakhir kampanye tersebut hingga saat ini. ${ }^{71}$

\section{Masyarakat Umum}

Mengingatkan kembali adalah merupakan hal yang menyakitkan. Namun, selama tujuan tersebut baik maka tidak ada salahnya cara tersebut untuk dicoba. Tentunya hal seperti ini tidak semua masyarakat setuju. Sehingga diharapkan kepada pihak-pihak yang mengadakan aksi mengingat kembali kerusuhan tersebut agar tetap menjaga sikap dan perbuatan agar tidak kembali menciderai perasaan keluarga korban. Karena bagaimana pun peristiwa tersebut sulit dilupakan, tetap tersimpan dalam ingatan. ${ }^{72}$

\section{Simpulan}

Berdasarkan hasil penelitian mengenai kasus konflik "Jum'at Kelabu" yang terjadi di Kota Banjarmasin pada 23 Mei tahun 1997 dapat disimpulkan bahwa konflik atau kerusuhan yang terjadi di Kota Banjarmasin merupakan konflik politik yang mengikut sertakan isu agama, dan kesenjangan ekomonisosial masyarakat Banjarmasin pada waktu itu. Sehigga kerusuhan ini dapat dikatakan bentuk kekecewaan masyarakat atas berbagai masalah yang menimpa bangsa Indonesia selama ini khususnya Kota Banjarmasin. Bermula dari Masjid Noor pada hari Jum'at pada saat putaran terakhir kampanye dari kubu Partai Golkar yang menyulut amarah jamaah karena merasa terganggu akan aksi massa simpatisan Partai Golkar. Sehingga pasca shalat Jum'at terjadilah kerusuhan besar di Banjarmasin yang kemudian merenggut banyak korban jiwa

\footnotetext{
${ }^{69}$ Diolah dari wawancara dengan Ibnu Arabi, Pandita Sharwa Dharma, Romo Alpharis dan H. Asnawi Thomas.

${ }^{70}$ Banjarmasin Post, "Sebagian Masyarakat Banjarmasin Masib Trauma”, 28 Mei 1997.

${ }^{71} \mathrm{H}$. Anang Hadrianoor, wawancara pribadi, Ketua Pengelola Masjid Noor Banjarmasin, Senin, 30 Mei 2016.

${ }^{72}$ Abdullah, wawancara pribadi, pedagang Pasar Sudimampir, 26 April 2016.
} 
dan materil. Namun, hingga kini kasus konflik tersebut tidak benar-benar diusut tuntas oleh pemerintah tentang siapa dalang/provokator dibalik peristiwa tersebut. Sehingga sebagian masyarakat Banjarmasin sampai saat ini masih berharap kasus ini dapat diusut tuntas, yaitu kasus konflik yang telah hampir 20 tahun berlalu dan merenggut banyak korban dari masyarakat sipil. Dan melalui rentetan kejadian konflik, membuktikan bahwa hal ini bukanlah peristiwa yang kecil. Karena banyak menelan korban jiwa, harta benda dan trauma psikologis yang mendalam.

Berbagai upaya dilakukan oleh elemen-elemen masyarakat (non gouvernmental actor) untuk tetap menjaga dan membangun perdamaian pasca konflik tahun 1997 di masa kini. Upaya-upaya yang dilakukan elemen-elemen masyarakat seperti aksi damai turun ke jalan (aksi menolak lupa), pembacaan sejarah, puisi dengan disertai aksi teatrikal, bernyanyi dan doa bersama, renungan, bagi-bagi bunga. Semua itu merupakan agenda rutin yang tiap tahun mereka lakukan. Langkah ini dianggap efektif untuk terus menjaga situasi yang telah damai agar konflik atau kerusuhan yang serupa "Jum'at Kelabu" tidak pernah terjadi lagi. Dan dengan menghadirkan kembali memori kolektif masa lalu ini, diharapkan dapat menjadi media atau alat dalam membangun damai dan resolusi konflik selanjutnya.

Peran elemen-elemen masyarakat memandang perlu adanya aksi menolak lupa di ruang publik agar masyarakat dapat mengambil i'tibar dari tragedi besar yang membawa dampak negatif bagi kota mereka. Tujuan lain dari kegiatan atau aksi ini adalah untuk intropeksi diri, bahwa kedamaian itu mahal dan berharga. Sehingga dibutuhkan kerjasama antara pemerintah dan elemenelemen masyarakat lainnya agar kehidupan yang damai dan penuh tenggang rasa dapat diwujudkan bersama tanpa gesekan-gesekan dan mengorbankan hajat hidup orang banyak.

\section{Daftar Pustaka}

A.A Wattinema, Reza, Indonesia, Nasionalisme dan Ingatan Kolektif: mengembangkan Nasionalisme Indonesia Melalui Penegasan Ingatan Kolektif, Melintas, 2009.

Abu Achmad, Abu dan Cholid Narbuka, Metode Penelitian. Jakarta: Bumi Angkasa, 2002.

Ali, Mursyid (ed.), "Pengantar", Pemetaan Kerukunan Kehidupan Beragama di Berbagai Daerah di Indonesia. Jakarta: Puslitbang Kehidupan Keagamaan, 2009. 
Baharudin M., "Filsafat Perenial Sebagai Alternatif Metode Resolusi Konflik di Indonesia", Jurnal Teologia, Volume 25, Nomor 1, Januari-Juni 2014.

Jamil M. Mukhsin, Resolusi Konflik: Model dan Strategi; dalam Mengelola Konflik Membangun Damai. Semarang: Wali Songo Media Center, 2007.

K. Olick Vered Vinitzky, Jefrey dan Seroussi Daniel Levy (ed.), The Collective Memory Reader. Oxford University Press, 2011.

Mujiburrahman, Mengindonesiakan Islam: Representasi dan Ideologi. Yogyakarta: Pustaka Pelajar, 2008.

Nata, Abuddin, Metodologi Studi Islam. Jakarta: Raja Grafindo Persada, 2008.

Nursasongko, Pekik, Atlas Tematik: Kota Banjarmasin. Klaten: PT Intan Prawira, 2011.

Rahmadi, Pengantar Metodologi Penelitian. Banjarmasin: Antasari Press, 2011.

Salim HS, Hairus dan Andi Achdian, Amuk Banjarmasin (Jakarta: Yayasan Lembaga Bantuan Hukum Indonesia (YLBHI), 1997.

Siregar, Darman, "Peta Daerah Konflik di Indonesia: Akar Masalah dan Pola Menaggulangi", Jurnal Harmoni I, No. 3, Juli-September 2003.

Sumodiningrat, Gunawan dan Ari Wulandari, Revolusi Mental: Pembentukan Karakter Bangsa Indonesia. Yogyakarta: Media Pressindo, 2015.

Sulistyo, Hermawan, "Anarki Enam Jam: Rekonstruksi Kerusuhan Jumat Membara di Banjarmasin", dalam Haris Syamsudin, Kecurangan dan Perlawanan Rakyat dalam Pemilihan Umum 1997, Jakarta: Yayasan Obor Indonesia, 1999.

Suwariyati, Titik, "Konflik-konflik Sosial Bernuansa Agama di Berbagai Komunitas: Kasus Kerusuhan Sosial di Banjarmasin 1997”, Departemen Agama RI, Konflik Sosial Bernuansa Agama di Indonesia (Jakarta: Badan Litbang Agama dan Diklat Keagamaan, Puslitbang Kehidupan Beragama, Bagian Proyek Peningkatan Kerukunan Hidup Umat Beragama, 2003.

\section{Wawancara}

Abdullah, pedagang Pasar Sudimampir,

Dhani, Anggota LK3 Banjarmasin.

Fathul, Pegawai BNPB.

H. Anang Hadrianoor, Ketua Pengelola Masjid Noor Banjarmasin.

H. Asnawi Thomas, Tokoh Partai, Ketua DPC PPP Tahun 1997.

Ibnu Arabi, tokoh Agama Islam. 
Maimunah, mayarakat Banjarmasin yang menyaksikan langsung konflik yang terjadi.

Nur Hayati dan Jambrut, keluarga korban.

Pandita Sharwa Dharma, Tokoh Agama Buddha.

Romo Alpharis, Tokoh Agama Kristen.

Riki, Anggota PMII IAIN Antasari.

Rizal Siddik, Ketua Umum STB UNISKA.

Sahbirin, penjaga Tempat Pemakaman Umum Landasan Ulin, Banjarbaru.

Saktiono Wahyujati, S.Sos, Kepala Seksi TVRI Kalimantan Selatan.

Sultan Igo Sanjaya, Mahasiswa UNLAM (BEM).

Zainul Muslihin, Ketua Umum ELSISK.

\section{Koran}

Banjarmasin Post, "Sebagian Masyarakat Banjarmasin Masib Trauma", 28 Mei 1997.

Banjarmasin Post "Komnas HAM Catat 6 Pelanggaran", Mei 1997.

Banjarmasin Post, "Polda Kalsel Temukan Selebaran Gelap". 26 Mei 1997.

Banjarmasin Post, "Mayoritas Ulama Dukung Golkar”, 23 Mei 1997.

Banjarmasin Post, "Komnas HAM: Belum Tentu yang Tewas Perusub”, 2 Juni 1997.

Banjarmasin Post, "Bakti Sosial”, Kamis 29 Mei 1997.

Banjarmsin Post, "Bakar Motor Warnai Kampaye Terakbir PDI", dan "Hari Ini Berkampanye Simpatik, Golkar Bagikan Hadiah”, Jum’at 23 Mei 1997.

Banjarmasin Post, "Dalam Peristiwa 23 Mei, Masib 197 Orang Hilang Belum Ditemukan", "Komnas HAM Belum Terima Laporan", "Sebagian yang Hilang Sudah Pulang Ke Rumah", 10-11 Juni 1997.

Dinamika Berita, "Hari Ini Golkar akan Tampil Habis-habisan", Jumat 23 Mei 1997

Dinamika Berita, "PDI dan PPP Habis-Habisan”, Jum'at 23 Mei 1997.

Dinamika Berita, "Korban Tewas Jadi 135 orang, 164 Warga Hilang, 181 Masih Diamankan", 26 Mei 1997, "Korban Tewas Sudah 142 Orang", "Tidak ada Korban Penembakan" , "Kasus Orang Hilang dalam Peristiwa 23 Mei"

\section{Internet}

http://kapotha.blogspot.co.id/2010/11/peacebuilding.html. https://www.facebook.com/Antasaria.Media?fref=nf.

https://haisa.wordpress.com/2007/05/23/10-tahun-amuk-jumat-kelabu-danmunir/\#comment-345. 
http://banjarmasinpost.co.id/istimewa, "Yuk! Nonton Film Dokumenter Jumat Kelabu di Gerobak. Coklat'.

http://banjarmasin.tribunnews.com/2015/05/23/masih-banyak-yang-antreingin-menyaksikan-film-jumat-kelabu.

http://www.antasaria.com/2016/05/aksi-menolak-lupa-tragedi-23-Mei1997.html.

http://banjarmasin.tribunnews.com/2016/05/23/setelah-19-tahun-tragedi-23mei-kuburan-massal-itu-kini-mulai-terlupakan.

https://haisa.wordpress.com/2007/05/23/10-tahun-amuk-jumat-kelabu-danmunir/\#comment-345.

https://www. facebook. com/Family-Bpfc-220038458182708/.

http://blog.Gilang Desti Parahita, Memori Kultural, Konflik, dan Media, Studi Kasus: Pertikaian Indonesia dan Malaysia atas Iklan "Enigmatic Malaysia". Lihat juga pada Neiger, M., Meyers, O., \& Zandberg, E. (Eds.). (2011). 'Introduction' On media memory: Collective Memory In a New Media age. New York: Palgrave Macmillan. 